\title{
Anna Kujawska-Kot
}

\section{Podmiot transseksualny w kulturze - oswajanie, tragizm, tekstualizacja}

\begin{abstract}
Kujawska-Kot Anna, Podmiot transseksualny w kulturze - oswajanie, tragizm, tekstualizacja [Transsexual subject in culture - taming, tragedy, textualization]. „Przestrzenie Teorii” 31. Poznań 2019, Adam Mickiewicz University Press, pp. 311-341. ISSN 1644-6763. DOI 10.14746/pt.2019.31.17.

The article presents the issue of the representation of a transsexual subject's experience in various discourses. Pointing to the need for dialogical openness, the author proposes a transdiscursive perspective on transsexuality. By referring to the literary and historical discourses, the author proves that transsexual characters are constantly present in culture, but there is lack of textological reflection on this issue in studies on transsexual individuals. The author puts forward the thesis that these transsexual characters are searching for hypotexts in which they can find confirmation of their internal gender identity. As a result, during the process of transistion, they externalize themselves through intertextual bodywriting. On the one hand, they textualize themselves, but on the other hand, they create textual narrations about themselves. They want to exist socially throughout the text. The article is an attempt to open up theoretical reflections on transsexuality.
\end{abstract}

KEYWORDS: transsexual character, transdiscursivity, gender identity, process of transistion, hypotexts, intertextual bodywriting, textualization

\section{Otwarcie dialogiczne na odmienność. Ujęcie transdyskursywne}

W krótkometrażowym filmie Možnosti dialogu [Dimensions of Dialogue] czeskiego animatora Jana Švankmajera, w sekwencji opatrzonej tytułem Dialog vášnivý [Passionato dialogue] przy drewnianym stoliku siedzą naprzeciwko siebie ulepieni z gliny: kobieta (po prawej stronie) i mężczyzna (po lewej). Widać ich twarze, usta. Wydaje się, że łączy ich bliska więź. On gładzi jej dłoń. Obejmują się, formują usta w charakterystyczne dzióbki do pocałunku. Nieoczekiwanie czułość rozrasta się wraz z połączeniem plastelinowej/glinianej formy męskiej i żeńskiej. W cielesnej bryle, co i raz pokazuja się dłonie, twarze, piersi. W rezultacie następuje rozdzielenie i z powrotem postaci odzyskują swoją wyrzeźbiona formę kobiecą i męską. Powracamy do ujęcia otwierającego przywołaną sekwencję: naprzeciwko siebie przy omszałym stoliku siedzi kobieta i mężczyzna, ale między nimi na blacie po wcześniejszej szamotaninie pozostaje kawałek gliny, który okazuje się ożywioną materia. Tworzywo, dotykając kobietę, próbuje zwrócić na siebie uwagę, pragnie dołączyć do 
jej ciała. Jednak ona odpycha je w stronę swojego partnera, który również odrzuca zanimizowaną materię. Gliniany odprysk pokonuje trudności związane ze szlakiem prowadzącym w stronę kobiety. Ta zaś, uznając go za obcy surowiec, próbuje zmiażdżyć rękoma. W rezultacie kawałek gliny trafia w ręce mężczyzny, który formuje z niego plastelinową śnieżkę i rzuca w kierunku kobiety. Bohaterka nie pozostaje dłużna, gliniasta kulka trafia w twarz mężczyzny. W ekspresyjnych gestach dochodzi do wzajemnego pozbawiania się twarzy, a powtórna szarpanina zamienia kobietę i mężczyznę w bezkształtną masę. Przyczyn owej przemiany można upatrywać $\mathrm{w}$ na pozór niepotrzebnym glinianym odpadzie albo w braku chęci objęcia swoim ciałem dodatkowego fragmentu, który z jakichś względów na środku drewnianej sceny został uznany za nieprzystający do zaprezentowanych postaci, niepotrzebny, Inny skrawek ciała, a agresja wobec niego nadała mu stygmat Obcego. Pochodzenie glinianej formy natychmiast zostało zapomniane przez kobietę i mężczyznę siedzacych przy stole. To, co odrzucili, wytworzyło się z ich ciał i uczuć. „Trzeci” zostaje ukształtowany z nich, ale jako Innego jego stwórcy w akcie nienawiści odrzucili.

Zatem jaka przyjąc postawę wobec istnienia wymykającego się jednoznacznemu rozpoznaniu, które postrzegane jest jako odmienne czy nawet obce? Próba porównania inności z obcością (Innego z Obcym) pozwala dostrzec pewną różnicę w kategoryzacji. Obcy z pewnościa „poddawany jest sądom wartościującym zazwyczaj o zabarwieniu negatywnym" ${ }^{1}$, natomiast Inny w konfrontującej optyce Obcego wydaje się bardziej swój, choć również odmienny, ale niepozbawiony możliwości istnienia. Kawałek gliny w ujęciu Švankmajera został finalnie uznany za obcy twór ze względu na zachwiana, niejednoznaczną przynależność do figury kobiety lub mężczyzny, ujawniał jedynie (a może aż) pragnienie współtworzenia kobiecego ciała. Natomiast migotliwość, nomadyczność jego formy spotkała się z wrogościa, dodatkowo niebezpieczna, bo wikłajacca w szereg destrukcyjnych zachowań siedzacych przy stole. Kawałek gliny wydobywający z siebie zarys rąk i nóg nie wpasował się w obowiązujące standardy, a ujęcie obrazujące trzymanie się plastelinowej materii krawędzi stołu można odnieść do sytuacji osób napiętnowanych, piszących na marginesie życia społecznego swoje historie. Nietypowość (której postrzeganie zależy od danej kultury) związana na przykład z cielesnością: fizyczne deformacje, wygląd ciała odbiegający od konwencjonalnych, stereotypowych wyobrażeń (od tego, co standardowe) powoduje u obserwatorów dysonans poznawczy, uruchamiajacy pro-

${ }^{1}$ E. Dabrowa, Kim jest dziś inny w Polsce?, [w:] Spogladajac na stereotyp, red. R. Kusek, J. Sanetra-Szeliga, Kraków 2014, s. 16. 
ces wykluczania osób odmiennych ${ }^{2}$. Zatem sposób, w jaki myślimy o ciele: czy kierujemy się szacunkiem czy niechęcia, zaciekawieniem czy odrzuceniem, pragnieniem zrozumienia czy pogarda, „wpływa na to, jak myślimy o tożsamości, inności, podmiotowości”. Powierzchnia ciała odgrywa rolę pośrednika pomiędzy podmiotem a jego środowiskiem ${ }^{4}$, jego postrzeganie wpływa zarówno na odbiór samego siebie, jak i innych osób. Jak zauważa Zygmunt Bauman: „Na ciele, podobnie jak na myślach i uczuciach, społeczeństwo odciska swój kształt”. Z Z kolei Erving Goffman zwraca uwagę, że podczas bezpośredniego spotkania można przerwać mówienie, ale nie można zaprzestać komunikowania za pośrednictwem ciała ${ }^{6}$, dlatego ciało w jego podmiotowym wymiarze w szczególny sposób narażone jest na etykietowanie, a mechanizm subiektywnego metkowania uprzedmiotawia człowieka. Nadanie jednostce/grupie społecznej (mniejszości) piętnujących atrybutów prowadzi do uprzedzeń, których efektem są działania wykluczające ${ }^{7}$, oscylujące między infrahumanizacją (dehumanizacją niejawna, polegająca na słabszym dostrzeganiu cech ludzkich w nieswojej grupie) a dehumanizacja. Konserwatyzm oraz strach przed kontaktem z jednostka/grupa wykluczona prowadzą do postrzegania obcych jako pozbawionych moralnej wrażliwości, niezasługujących na ludzkie traktowanie, co z kolei ułatwia agresję wobec nich i daje przyzwolenie na krzywdzenie wykluczonych ${ }^{8}$. Paradoksalnie istnienie grup odrzucenia pozwala dać upust własnym frustracjom, a także przyczynia się do samoidentyfikacji grupy dominującej, która i w taki sposób buduje swoją tożsamość 9 . Natomiast jednostka odrzucona, przeglądając się w społecznym lustrze, może uruchomić mechanizm samodestrukcji. Jej poczucie wyalienowania zwykle związane jest z jej samotnościa, ponieważ tendencja do rozprzestrzeniania się piętna z nosiciela na osoby blisko z nią

${ }^{2}$ Por. M. Kondracka, Spotkanie z Innym - refleksje teoretyczno-empiryczne, [w:] Spoteczeństwo wobec Innego. Kategoria Innego w naukach społecznych $i$ życiu publicznym, red. L. Dziewięcka-Bokun, A. Śledzińska-Simon, Toruń 2010, s. 67 i E. Goffman, Piętno. Rozważania o zranionej tożsamości, tłum. A. Dzierżyński, J. Tokarska-Bakir, Gdańsk 2005, s. 11.

${ }^{3}$ M. Rogowska-Stangret, Ciało - poza Innościq $i$ Tożsamościa. Trzy figury ciała $w$ filozofii wspótczesnej, Gdańsk 2016, s. 7.

${ }^{4}$ Por. tamże, s. 269.

${ }^{5}$ Z. Bauman, Ponowoczesne przygody ciała, [w:] tegoż, Ciało i przemoc w obliczu ponowoczesności, Toruń 1995, s. 70.

${ }^{6}$ Por. E. Goffman, dz. cyt., s. 12.

${ }^{7}$ Por. J. Erenc, Teoria grupy społecznej a mechanizmy wykluczenia, [w:] Spotecznie wykluczeni. Niewygodni, nienormatywni, nieprzystosowani, nieadekwatni, red. A.M. Kłonkowska, M. Szulc, Gdańsk 2013, s. 20.

${ }^{8}$ Por. M. Tarnowska, Kiedy odmawiamy „obcym” części człowieczeństwa? Uwarunkowania zjawiska infrahumanizacji, [w:] Wobec obcych. Zagrożenia psychologiczne a stosunki międzygrupowe, red. M. Kofta, M. Bilewicz, Warszawa 2011, s. 186, 169, 180 i 181.

${ }_{9}^{9}$ Por. J. Erenc, dz. cyt., s. 22. 
„związane jest powodem, dla którego takich relacji zwykle się unika, a jeśli już istnieja, to się je zrywa"10.

Wobec tego problem spotkania z Innym/Obcym ciagle jest aktualny, a pytania zadane między innymi przez Ryszarda Kapuścińskiego: „Jak odnieść się do Innych? Jaką zająć wobec nich postawę?"11 nie tracą na ważności. Pisarz wymienia trzy możliwości spotkania się z Innym: wojnę, odgrodzenie się murem, nawiązanie dialogu ${ }^{12}$. Biorąc pod uwagę złudzenie, jakie daje status swojskości i fakt, że Odmieńcem, Innym czy Obcym może być każdy $\mathrm{z}$ nas ${ }^{13}$, rozmowa oprócz po prostu ludzkiego wymiaru może w najzwyklejszy sposób zainteresować, zaintrygować, dać prawdziwe poczucie bezpieczeństwa. Z pewnością otwarcie dialogiczne na różnorodność przyczynia się do rozwoju człowieka/społeczeństwa. Brak włączenia w dyskurs Innego/Obcego tworzy z relacji międzyludzkich (jak to plastycznie i namacalnie przedstawił Švankmajer) bezkształtna, zbitą masę. Działa destrukcyjnie, a w kontekście sporów dotyczących inności, braku tolerancji dla niej, dochodzi do eskalacji zła, działań autodestrukcyjnych i wzajemnie destrukcyjnych, braku porozumienia, wręcz wrogości.

Według Martina Bubera dla dialogu z drugim człowiekiem kluczowa jest sama sytuacja spotkania ${ }^{14}$, natomiast, aby doszło do prawdziwego dialogu, konieczna jest akceptacja inności, przekonanie o wartości Innego, którego tożsamość kształtowana, uzgadniana jest w trakcie interakcji społecznych. Z kolei Zygmunt Bauman wskazuje na wyjątkowość Innego. Może ona stanowić zachętę do stanięcia z nim twarzą w twarz, do rozmowy. Inny jawi się nam jako ktoś wyjątkowy i jako taki wzbudza nasze zdziwienie; wart jest poznania i nawiązania bliższej relacji ${ }^{15}$. Co zrobić jednak w sytuacji, gdy inność, wiążąca się z alienacja, wykluczeniem, uwikłana jest w płciowość podmiotu, a u podstaw braku akceptacji i/lub samoakceptacji leży nieadekwatność, rozbieżność między ciałem a psychiką? Wydaje się, że należy skierować się w stronę okaleczonego podmiotu i skoncentrować się na nim. Zatem celem niniejszego artykułu jest zaprezentowanie transseksualności

${ }^{10}$ E. Goffman, dz. cyt., s. 64.

${ }^{11}$ R. Kapuściński, Spotkania z Innym jako wyzwanie XXI wieku. Wykład wygłoszony 1 października 2004 z okazji przyznania tytułu doktora honoris causa Uniwersytetu Jagiellońskiego, Kraków 2004, s. 9.

${ }^{12}$ Por. tamże, s. 10.

${ }^{13}$ Por. B. Darska, Wstęp. Patrzeć z nieufnościa, [w:] Kultura wobec odmienności. Dyskursy. Film/Telewizja t. 1, red. B. Darska, Warszawa 2009, s. 6.

${ }^{14}$ Por. K. Rosner, Dialog jako temat filozofii wspótczesnej: Buber, Gadamer, Habermas, [w:] Dialog. Idea i doświadczenie, red. S. Kruszyńska, K. Bembennek, I. Krupiecka, Gdańsk 2011, s. 19.

${ }^{15}$ Por. Z. Bauman, What chance of ethics in the globalized World of consumers?, [w:] Does Ethics Have a Chance in a World of Consumers?, London 2009, s. 42. 
jako zagadnienia kulturowego, tekstowego, ale i medyczno-społecznego. Spotkanie z tym rodzajem transpłciowości ${ }^{16}$ ma również na celu wytworzenie podstaw do dialogu badawczego.

Podmiot transseksualny obecny jest w różnych dyskursach: socjologii, psychologii, medycyny, historii i sztuki. Ze względu na charakter podmiotu konieczne jest ujęcie transdyskursywne. Warto zauważyć, że w dyskursie artystycznym narracje osób transseksualnych, a także cispłciowych ${ }^{17}$ o transseksualnych bohaterach wpisuja się $\mathrm{w}$ proces powrotu podmiotu, rozumianego jako autor, ale również jako postać literacka czy filmowa. Ryszard Nycz dla podmiotu, który jest równocześnie empiryczny i tekstowy, autentyczny i fikcyjno-literacki, stworzył specjalny termin: ,ja sylleptyczne"18. Teksty, które prezentuja autora i/lub prezentują bohatera sa „dramatocentryczne, ponieważ domagają się ukazania obecności” ${ }^{19}$, dają

${ }^{16}$ Transpłciowość „to termin używany na określenie całego spektrum osób [...] nie identyfikujących się - choć w różnym stopniu i w różny sposób - z przypisaną im w momencie urodzenia i/lub związaną z nią płcią kulturowa. Osoby transpłciowe określane sa jako trans kobieta (m/k, ang. MTF) - jeśli urodziły się z ciałem uznawanym za biologicznie męskie i przyjmują kobiecą tożsamość, często też (choć nie zawsze) podejmują kroki w kierunku skorygowania swojego ciała i/lub tożsamości prawnej w kierunku kobiecym; lub trans mężczyzna (k/m, ang. FTM) - jeśli urodziły się z ciałem uznawanym za biologicznie kobiece i przyjmuja męską tożsamość, często też (choć nie zawsze) podejmuja kroki w kierunku skorygowania swojego ciała i/lub tożsamości prawnej w kierunku męskim [...]. Należy jednak zaznaczyć, że nie każda osoba transpłciowa określa swoją tożsamość płciową w kategoriach dychotomii kobieta - mężczyzna. Część osób transpłciowych identyfikuje się z obiema uznawanymi społecznie płciami, część nie identyfikuje się z żadną z nich, lokując swoją tożsamość poza kategoriami płci w ogóle”. A.M. Kłonkowska, Płeć: dana czy zadana? Strategie negocjacji (nie) tożsamości transpłciowej w Polsce, Gdańsk 2017, s. 14.

W tym miejscu warto zwrócić uwagę za Renatą Ziemińską na termin „osoby niebinarne”. Badaczka, powołując się na raport z 2016 roku organizacji Scottish Trans Alliance na temat życia osób niebinarnych w Wielkiej Brytanii, przytacza definicję „osoby niebinarnej”, a zatem jest nią osoba „identyfikująca się albo jako posiadająca płeć pomiędzy lub poza dwiema kategoriami «mężczyzna» i «kobieta», albo jako osoba fluktuująca między «mężczyzną» i «kobietą", albo jako osoba nieposiadająca żadnej identyfikacji płciowej”. Wedle tej definicji - podsumowuje Ziemińska - „sa trzy warianty niebinarności: posiadanie trwałej tożsamości pomiędzy/poza dwiema płciami, posiadanie płynnej tożsamości, która raz jest męska, a innym razem żeńska, i wreszcie brak identyfikacji płciowej”. R. Ziemińska, Niezgodność ptci odczuwanej z ptciq metrykalna. Osoby transptciowe, [w:] Niebinarne i wielowarstwowe pojęcie ptci, Warszawa 2018, s. 88, 89.

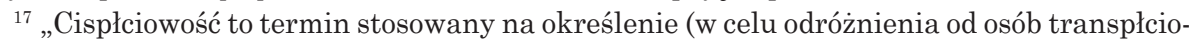
wych) osób utożsamiających się z płcią rozpoznaną w momencie narodzin”. A.M. Kłonkowska, dz. cyt., s. 9 .

${ }^{18}$ Myśl tę parafrazuje Jerzy Bartmiński. Zob. J. Bartmiński, Polifoniczność tekstu czy podmiotu? Podmiot $w$ dialogu z samym sobq, [w:] Podmiot w języku i kulturze, red. J. Bartmiński, A. Pajdzińska, Lublin 2008, s. 168.

${ }^{19}$ A. Zieniewicz w: Aneks. Podmiot w literaturze po 1989 roku. Cudownie zmartwychwstały, [w:] Podmiot w literaturze polskiej po 1989 roku. Antropologiczne aspekty konstrukcji, red. Ż. Nalewajk, Warszawa 2011, s. 292. 
namacalne świadectwo istnienia osób transpłciowych, przybliżają odbiorcy horyzonty ich przeżyć, zmagań. Doświadczenia reprezentowane przez literaturę, film, dzieła plastyczne nawet jeśli nie są autobiograficzne, odnoszą się do jednostki i jej relacji ze społeczeństwem. Przedstawianie siebie przez transpłciowych bohaterów jednocześnie bliskie jest aktowi kreacji postaci literackiej czy filmowej. Podobny proces zachodzi w przypadku postaci fikcyjnej, wykreowanie jej indywidualnej opowieści w powiązaniu (z reguły) z innymi bohaterami, których transpłciowość lub cispłciowość jest wyraźnie zasygnalizowana. Transseksualny (ale również transwestytyczny, cispłciowy) podmiot można rozpatrywać zarówno ,jako ślad, jako akt konstytuowania narracyjnej tożsamości oraz jako zagadnienie etyczno-empiryczne" ${ }^{\prime 2}$. W narratywistycznej koncepcji podmiotu, wiążącej się z kategorią tożsamości narracyjnej, nieustannie dochodzi do interferencji literatury, sztuki filmowej i rzeczywistości ${ }^{21}$. Opowieść o własnym życiu, empatyczne przybliżenie cudzej historii jednocześnie scala je w narracji. Takie pojmowanie podmiotu, na co wskazuje Bogumiła Kaniewska, stanowi nowa szansę dla literaturoznawstwa, zmęczonego już abstrakcyjnym bytowaniem poza aksjologia i etyką ${ }^{22}$. Zatem język literatury czy filmu traktowany jest jako struktura myślenia i interpretacji nieodłącznie związana z samym życiem, co zgodne jest z koncepcja Charlesa Taylora ${ }^{23}$. Według kanadyjskiego filozofa „w akcie świadomej, choć nieskończonej językowej autokreacji współczesny człowiek odnajdzie prawdziwy świat, a w nim własną (prawdziwa) tożsamość" ${ }^{4}$. $\mathrm{Z}$ tego powodu dla bohaterów tak istotne jest zaistnienie $\mathrm{w}$ języku. Taylor w swoich rozważaniach przedstawia, jak ważne dla podstaw etyki jest „wyartykułowanie nieznanego, niewiadomego i wprowadzenie go niejako w obieg społeczny"25. Badacz rezygnuje z (typowego dla klasycznej filozofii) przekonania o dualizmie języka i świata. Zatem historie osób transseksualnych zapisane, wypowiedziane w narracji literackiej i filmowej nakładają się na narracyjne ludzkie egzystencje. Także psychologowie coraz bardziej doceniają „rolę języka, dialogu, opowiadania o sobie dla kształtowania poczucia podmiotowości. Rozwijająca się w ostatnim okresie psychologia narracyjna wiąże tożsamość podmiotu osobowego ze zdolnością człowieka do kreowania rozmaitych autohistorii” ${ }^{26}$.

${ }^{20}$ B. Kaniewska, „I tak taki jest się, jaki jest”- wokót kategorii podmiotu literackiego, [w:] Podmiot w języku i kulturze, red. J. Bartmiński, A. Pajdzińska, Lublin 2008, s. 104.

${ }^{21}$ Por. tamże, s. 105.

${ }^{22}$ Por. tamże, s. 107.

${ }^{23}$ Por. B. Choińska, Podmiot $i$ dyskurs $w$ świetle myśli wybranych przedstawicieli postrukturalizmu francuskiego, Kraków 2014, s. 292.

${ }^{24}$ Tamże, s. 297.

${ }^{25}$ Tamże, s. 298.

${ }^{26}$ J. Bartmiński, dz. cyt., s. 177-178. 
Henryk Markiewicz w swojej umiarkowanie antropomimetycznej koncepcji postaci połączył to, co zwykle odbierane było jako konfliktowe: człekokształtność oraz tekstowość, a co ma fundamentalne znaczenie dla niniejszej koncepcji ${ }^{27}$. Nawet jeśli mamy do czynienia (przez odbiór dzieła literackiego czy filmowego) z fikcyjnymi postaciami, nie możemy wykluczyć ich podobieństwa do ludzi rzeczywistych ${ }^{28}$.

\section{Transpłciowość jako temat i motyw w kulturze}

Świadectwa istnienia bohatera transpłciowego możemy odnaleźć w dawnej, jak i współczesnej kulturze, choć wyodrębnienie w dalekiej historii rozszczepionego podmiotu, niezgadzającego się na ciało, które posiada; utożsamiającego się z przeciwną płcią, nie jest sprawą prostą. Poszukiwania przejawów transseksualności ${ }^{29} \mathrm{w}$ przeszłości nie do końca dadzą się zweryfikować, ponieważ tak istotne dla współczesnej diagnostyki rozróżnienie zachowań charakterystycznych dla transseksualizmu i odrębnych dla transwestytyzmu zaczęło funkcjonować dopiero na początku XX wieku pod wpływem prac Magnusa Hirschfelda Transvestism: An Investigation into the Erotic Impulse of Disguise (1910) oraz Havelocka Elisa ${ }^{30}$. Poza tym kategoria płci (która od lat osiemdziesiątych XX wieku pod wpływem teorii feministycznych została postawiona pod znakiem zapytania i to zarówno kategoria płci biologicznej, jak i kulturowej) wcale wcześniej (jeszcze przed ujęciem płci z perspektywy esencjalistycznej) nie była tak jednoznaczna, jak to jest właśnie w esencjalizmie, szukającym wzorów kobiecości i męskości w biologii. Jak dowodzi Thomas Lacqueur w Making Sex. Body and Gender form the Greek to Freud od antyku aż po wiek XVIII w kobiecie widziano jedynie mniej doskonałą wersję mężczyzny (narządy męskie miały być ukryte

${ }^{27}$ Edward Kasperski wskazuje na Henryka Markiewicza. Zob. E. Kasperski, Między poetyka i antropologia postaci. Szkic zagadnień, [w:] Postać literacka. Teoria i historia, red. nauk. E. Kasperski, współred. B. Pawłowska-Jądrzyk, Warszawa 1998, s. 10. Henryk Markiewicz zwrócił jednak uwagę, że kategorie mimesis oraz osobowości zawodzą ,tam, gdzie dominuje fantazja lub fantastyka, dydaktyka, artystyczna umowność, groteska, gra językowa lub deformacja” w: tamże.

${ }^{28}$ Por. tamże, s. 35.

${ }^{29}$ Używam terminu transseksualność zamiennie z transseksualizmem, choć pierwszy termin występuje w niniejszym szkicu częściej z uwagi na preferencje osób transseksualnych. Por. A.M. Kłonkowska, dz. cyt., s. 16.

${ }^{30}$ Por. A. Kusiak, Pamiętniki Pani de Sancy przebranej za opata. Transgenderyzm na dworze Ludwika XIV, [w:] Odmiany odmieńca. Mniejszościowe orientacje seksualne w perspektywie gender, red. T. Basiuk, D. Ferens, T. Sikora, Katowice 2002, s. 25-26; K. Krasuska, Transgender, [w:] Encyklopedia gender. Pteć w kulturze, red. M. Rudaś-Grodzka, K. Nadana-Sokołowska, A. Mrozik, K. Szczuka, K. Czeczot, B. Smoleń, A. Nasiłowska, E. Serafin, A. Wróbel, Warszawa 2014, s. 546. 
wewnątrz jej ciała ${ }^{31}$. W konsekwencji płeć społeczna w porównaniu z płcią biologiczną mogła być bardziej wyraźna. Zatem trafne wydaje się uchwycenie z odległych czasów zachowań, odczuć charakterystycznych dla osób transpłciowych, a nie wyłącznie dla osób transseksualnych.

Za jedno z pierwszych świadectw istnienia osób transpłciowych czy też należących do tak zwanej trzeciej płci ${ }^{32}$ można uznać odnalezione inskrypcje na pozostałościach ceramiki egipskiej datowanej na lata 2000-1800 p.n.e., gdzie wymieniani są mężczyźni, kobiety oraz eunuchowie ${ }^{33}$. Jak pisze Tomasz Jakubowski w Inności poprzez wieki - historii transptciowości:

Według niektórych badaczy, osobą transpłciową była Hatszepsut, kobieta faraon z XVIII dynastii, panująca w Egipcie na przełomie XVI i XV stulecia p.n.e. Istnieje kilka jej wizerunków, na których jest przedstawiona jako kobieta posiadająca penis, co może właśnie o tym świadczyć. [...] Ktezjasz, grecki autor „Historii Persji i Dziejów Persji” pisał o asyryjskim władcy Assurbanipalu, który po kryjomu, przebywając ze swymi konkubinami, przywdziewał kobiecy ubiór. [...] Z kolei Herodot, w swoich „Dziejach”, wspomina o tzw. enarëes wśród Scytów. Byli to mężczyźni noszący damski ubiór i posiadający dar jasnowidzenia. Autor podkreśla ich wysoki status społeczny i opisuje respekt oraz strach, jaki wzbudzali wśród pospolitego ludu [...]. Podobna grupe stanowili gallowie, czyli kapłani frygijskiej bogini Kybele, której kult przyją się również w Imperium Romanum. Byli to pod względem biologicznym mężczyźni, którzy w rytuale inicjacyjnym zwanym dies sanguinis dokonywali samokastracji i przywdziewali kobiece ubiory ${ }^{34}$.

Warto wspomnieć, że o „istnieniu trzech płci, męskiej, żeńskiej oraz androgynicznej, pisał ok. 400 roku p.n.e. Platon w dziele zatytułowanym Symposium. Kolejnym świadectwem występowania tego zjawiska w kulturze greckiej, a potem i rzymskiej, jest mit o Hermafrodycie" 35 . Hermafrodytyzm

${ }^{31}$ Por. A. Wieczorkiewicz, Dziwna kobiecość Barbary Urselin, [w:] Ucieleśnienia II. Pteć między ciatem i tekstem, red. J. Bator i A. Wieczorkiewicz, Warszawa 2008, s. 65.

${ }^{32}$ Współcześnie terminem trzeciej płci antropolodzy określają alternatywne modele gender w kulturach pozaeuropejskich. Por. J. Sieradzan, Ile ptci ma człowiek, „ALBO albo. Problemy Psychologii i Kultury” 2009, nr 2-3, Androgynia - miłość, red. Z.W. Dudek, Warszawa 2011, s. 120. Więcej o alternatywnych modelach męskości czy niestandardowych wariantach kobiecości (np. berdasze, alayha, nádleeh, warrhameh, hwame, hateneman, hidżra, sadhin, tobelije, ostojnice, katoi, mak pak nyah, pak nyah, waria, bissu, bakla, Hua) w: K. Arcimowicz, Pteć pierwsza, druga i trzecia. Alternatywne modele gender w kulturach pozaeuropejskich, [w:] Ucieleśnienia II. Pteć między ciałem i tekstem, red. J. Bator i A. Wieczorkiewicz, Warszawa 2008; J. Gajda, Trzecia pteć, [w:] Antropologia kulturowa. Kultura obyczajowa poczatku XXI wieku, Kraków 2015 i J. Sieradzan, dz. cyt.

${ }^{33}$ Por. T. Jakubowski, Inność poprzez wieki - historia transptciowości, [w:] Inność/ Różnorodność w języku i kulturze, red. E. Bogdanowska-Jakubowska, Katowice 2015, s. 113.

${ }^{34}$ Tamże, s. 113.

${ }^{35}$ Tamże. Przykłady współczesnych literackich i filmowych prezentacji problematyki interpłciowości, interseksualności (dawniejsze określenie hermafrodytyzm): Hermafrodyta Aleksandra Wata, $X X Y$ w reżyserii Lucii Puenzo. 
(w przeciwieństwie do androgynii) wyobraża stan niechciany, narzucony przypadkowo przez naturę ${ }^{36}$. Nimfa wodna Salmacys w swej zapalczywej miłości zespoliła się z Hermafrodytem, wikłając go w nową tożsamość, która spowodowała w nim rozdarcie między psychiką a ciałem noszącym znamiona obu płci.

Za osoby transpłciowe uważani są też przez badaczy niektórzy cesarze rzymscy. Według Jakubowskiego,

[o]mawiając zjawisko transpłciowości w kontekście kultury rzymskiej, nie sposób nie wspomnieć o [...] cesarzach: Kaliguli [...] i Heliogabalu. O Kaliguli, który panował w pierwszej połowie I wieku, wiadomo, że zainicjował wśród rzymskich cesarzy noszenie ubrania typowego dla płci odmiennej, jednak nie wykastrował się ani też nie golił brody. Swetoniusz wspominał, że Kaligula pewnego razu pojawił się publicznie przebrany za boginię Wenus. [...] Heliogabal, żyjący i panujący w pierwszej ćwierci III wieku, według relacji Kasjusza Dio, zawartej w „Historii Rzymu”, wykastrował się, przywdział kobiecy ubiór oraz prostytuował się na ulicach Rzymu. Pragną też, aby medycy stworzyli u niego żeńskie narządy płciowe [...]. Harry Benjamin [...], jeden z pionierów badań nad transseksualizmem, uważa, że Heliogabal jest pierwszą w historii możliwą do zdiagnozowania transseksualistką ${ }^{37}$.

Z kolei Bogusław Antoszewski przywołuje jeszcze inny fakt z życia rzymskiego cesarza, mianowicie to, że Heliogabal poślubił swojego niewolnika Hieroklesa ${ }^{38}$.

W dyskursie historii, zwłaszcza w przekazach pamiętnikarskich, odnaleźć można świadectwa uzewnętrzniania ekspresji związanej na przykład z transwestytyzmem. I tak na przykład Henryk Walezy, były król Rzeczypospolitej Obojga Narodów, ówczesny król Francji, w 1577 roku przyją emisariuszy przebrany za kobietę, a Abbe de Choisy, a właściwie François Timoléon de Choisy, arystokrata z bliskiego otoczenia Ludwika XIV, partner królewskiego brata Filipa Orleańskiego otwarcie chodził do Palais Royal w sukni ${ }^{39}$. Natomiast

[n]a tronie Szwecji zasiadała osoba uważana przez niektórych za transpłciową - królowa regentka Krystyna Waza. Od dzieciństwa miała się za osobę płci przeciwnej i nosiła ubiór męski. Miała też staranne wykształcenie, niedostępne kobietom jej czasów, interesowała się problematyką wojenna. W 1654 zrezygnowała z tronu Szwecji i wyjechała za granicę, gdzie żyła pod imieniem księcia Dohna [...]. Przypadki tego typu odmienności były także w Ameryce Północnej. Oprócz przykładów wskazujących na brak tolerancji wobec osób transpłciowych istnieja jednak też takie, które świadczą o czymś

${ }^{36}$ Por. K. Mrówka, Androgyn, Szczecin 2005, s. 11, 69, 70, 74.

${ }^{37}$ T. Jakubowski, dz. cyt., s. 113-115.

${ }^{38}$ Por. B. Antoszewski, Wizerunek transseksualisty typu kobieta-mężczyzna i suplement do etiopatogenezy zespołu dezaprobaty płci. Rozprawa habilitacyjna, Łódź 2009, s. 10.

${ }^{39}$ Por. T. Jakubowski, dz. cyt., s. 117. Analizą pamiętników de Choisy zajęła się Alicja Kusiak w Pamiętniki Pani de Sancy... 
wręcz odwrotnym. Tak było z Tomasine Hall, urodzoną jako mężczyzna, ale czująca przynależność do obu płci mieszkanką kolonii Wirginia. 8 kwietnia 1629 roku Sąd Główny dla kolonii Wirginia przyznał jej prawo noszenia elementów ubioru zarówno kobiecego, jak i męskiego, oraz nakazał uważać ją za osobę przynależącą do obu płci ${ }^{40}$.

We współczesnej literaturze odnajdujemy teksty, które koncentruja się na nietypowym zachowaniu bohaterów w zakresie doboru strojów, strzyżenia włosów. Na przykład Ernest Hemingway w Rajskim ogrodzie wielokrotnie opisuje doznania bohaterki Katarzyny Hall po wizycie u fryzjera. Katarzyna obcina swoje długie włosy i wybiera chłopięca fryzurę męża. Jej orientacja seksualna i w pewnej mierze tożsamość płciowa staja się coraz bardziej niejednoznaczne, choć ciagle punktem odniesienia jest dla niej mąz, który ulega jej fantazjom. Katarzynę nudzi własna kobiecość, od czasu do czasu chce być Piotrem ${ }^{41}$, poszukuje ciagle nowych wrażeń, również w zakresie lesbijskiej miłości. Akceptuje swoją fizyczność, ale podważa heteronormatywną oraz monogamiczną matrycę. Staje się androgyniczna.

Z kolei literackiej egzemplifikacji pragnień, przeżyć zbieżnych z doznaniami Heliogabala można doszukiwać się w Domu dziennym, domu nocnym Olgi Tokarczuk. W powieści zobrazowała autorka pragnienie posiadania znamion, atrybutów drugiej, przeciwnej płci. Kummernis (bohaterka powieści), której losy zostały poddane obróbce przez spisującego jej żywot Paschalisa, jawi się jako istota święta, dotknięta przez palec Boży. Pragnie wyzbyć się daru urody, który stał się dla niej przekleństwem. Unika gwałtu dzięki cudownemu zdarzeniu - zostaje bowiem obdarzona twarza Chrystusa i jego jedwabistą broda ${ }^{42}$, łacząc w sobie zewnętrzne cechy kobiece i męskie. Bohaterka (zasztyletowana i przybita do krzyża przez ojca) w świecie powieści staje się patronką wszelkich zmian ${ }^{43}$. Natomiast jej fikcyjny biograf, mnich Paschalis, współcześnie mógłby być zdiagnozowany jako transseksualistka ${ }^{44}$. Paschalis wyobraża sobie, że jest kobieta. „Ma

${ }^{40}$ T. Jakubowski, dz. cyt., s. $117-118$.

${ }^{41}$ Por. E. Hemingway, Rajski ogród, tłum. M. Michałowska, Warszawa 1989, s. 61, 24.

${ }^{42}$ Por. O. Tokarczuk, Dom dzienny, dom nocny, Kraków 2011, s. 88.

${ }^{43}$ Tamże, s. 223. Kummernis, jak podaje Marzena Lizurej: „nie została uznana przez Kościół katolicki, a jej wizerunki, przedstawiające kobietę rozpiętą na krzyżu, tłumaczy się jako pomyłkę pielgrzymów, którzy, przyzwyczajeni do przedstawienia nagiego ukrzyżowanego Chrystusa, obraz "Volto Santo», gdzie Zbawiciel ma na sobie królewskie szaty, interpretowali jako postać kobiecą" w: Mit androgyne - wzór tamania barier ptci. Teoria queer wobec powieści Olgi Tokarczuk „Dom dzienny, dom nocny”, [w:] Zrozumieć płeć. Studia interdyscyplinarne II, red. A. Kuczyńska, E.K. Dzikowska, Wrocław 2004, s. 510.

${ }^{44}$ Transseksualistka to osoba urodzona z biologicznie męskim ciałem, identyfikująca się z płcią kobieca, zaś transseksualista to osoba urodzona z biologicznie kobiecym ciałem, identyfikująca się z płcią męska. Por. W. Dynarski, A. Kłonkowska, Słownik pojęć, [w:] Sytuacja 
długie włosy, które spływają mu po plecach. Suknia ciasno opina mu krągłe piersi delikatnymi, cudownymi falami spływa po ziemi" ${ }^{55}$. W rezultacie chce doświadczać somatycznej kobiecości ${ }^{46}$. Mnich uwikłany jest w obcą dla niego chłopięca/męską cielesność, wobec której odczuwa niechęć, a nawet wstręt. W akcie rozpaczy „,chce iść do Rzymu i poprosić papieża, żeby uznał go za kobietę. Wtedy dopiero wróci jako pełnoprawna zakonnica"47. Ale to, na co może sobie pozwolić, to marnej jakości protezy kobiecości: sukienka i dziurawe pończochy prostytutki Katki. Pragnienie Paschalisa pozostało w sferze marzeń, nie doświadczył cudu korekty płci albo też urodził się zbyt wcześnie, kiedy jeszcze korekta płci nie była możliwa.

Inna sytuację związaną z zamienialnością mężczyzny i kobiety można odnaleźć w W Krainie Czarnoksiężnika Oza. Przemiana opisana przez Lymana Franka Bauma nie dotyczy już tylko stroju i nie jest chwilowa, odwracalna. Główny bohater, Tip, okazuje się księżniczką Ozma, prawowitą władczynią Szmaragdowego Grodu, zamienioną niegdyś przy użyciu czarnej magii w chłopca. Kreacji dzieła na opak dokonała wiedźma Ognicha, która dzięki interwencji dobrej wróżki Gladioli, przywraca jej prawdziwą postać. Mimo wcześniejszych obaw Tipa, co do jego/jej dalszych relacji z przyjaciółmi zostaje przez nich w pełni zaakceptowany/zaakceptowana i entuzjastycznie przywitany/przywitana w nowej, kobiecej formie.

W sposób równie bezbolesny dokonuje się transgresja innej postaci literackiej: przemiana Orlanda w Orlandę w powieści biograficznej (z anarchizującym elementem fantastyki ${ }^{48}$ ) Virginii Woolf. Metamorfoza odbywa się w Konstantynopolu. Orlando po sześciu dniach letargu/snu nagle budzi się, przegląda „od góry do dołu w długim zwierciadle”49 (a jest nagi) i konstatuje, że jest kobieta, „nie okazując najmniejszego zmieszania” ${ }^{50}$. „Przemiana odbyła się bezboleśnie, całkowicie i nie wzbudziła w Orlandzie żadnego zdziwienia" ${ }^{1}$. Orlanda pozostała spokojna. Niespiesznie zauważa wady i zalety

osób LGBT. Raport za lata 2010 i 2011, red. M. Makuchowska, M. Pawlęga, Warszawa 2012, s. 226 i A.M. Kłonkowska, dz. cyt., s. 15.

Wcześniejsze określenie transseksualista do trans kobiet było obraźliwe, bo ignorowało ich identyfikację, przypisując im w języku rodzaj męski, por. M.A. Pelczar, Co i kto nie „przechodzi”. (Nie)widoczność, „passing” a nie/normatywność trans, [w:] Strategie queer. Od teorii do praktyki, red. M. Kłosowska, M. Drozdowski, A. Stasińska, Warszawa 2012, s. 253.

${ }^{45}$ O. Tokarczuk, dz. cyt., s. 104.

${ }^{46}$ Por. tamże, s. 107, 110-111.

${ }^{47}$ Tamże, s. 141.

${ }^{48}$ Por. U. Terentowicz-Fotyga, „Drugi koniec świata”: Orlando i Fale, [w:] tejże, Semiotyka przestrzeni kobiecych w powieściach Virginii Woolf, Lublin 2006, s. 82, 73.

${ }^{49}$ V. Woolf, Orlando, tłum. T. Bieroń, Poznań 1994, s. 93; por. scena z filmu w reż. Sally Potter Orlando ukazujacca bohaterkę w planie pełnym.

${ }^{50}$ Tamże.

${ }^{51}$ Tamże. 
transgresji. Do walorów zalicza: kokietowanie mężczyzn (opieranie się i ustępowanie; ustępowanie i opieranie się), pełniejsze doświadczanie kontemplacji, samotności i miłości52 ${ }^{52}$ zaś do ułomności nowej sytuacji: fryzowanie włosów, zakładanie i sznurowanie gorsetu oraz nieustające zmiany strojów „z jedwabiów w koronki, z koronek w brokatelę" ${ }^{53}$. Jednak w odwrotnej sytuacji, gdy jest świadkiem cudzej transgresji, nie potrafi być opanowana i reaguje bardzo emocjonalnie. Przeobrażenie Harriety Griseldy von Finster-Aarhorn Scand-op-Boom w arcyksięcia Harry'ego budzi w niej strach ${ }^{54}$. Orlanda wielokrotnie wciela się w różne role. Podkreśla na zewnątrz dychotomiczny podział płciowy, ale jednocześnie czerpie doświadczenia istotne dla obu płci.

Dyskursy literacki i historyczny dowodza, że bohater transpłciowy stale jest obecny w kulturze. Szczególną formą transpłciowości jest transseksualność. Specyfika podmiotu transseksualnego polega na rozbieżności między wewnętrznym poczuciem swojej płci a tym, kogo widzi w lustrze; między tym, jak chciałby być postrzegany pod względem płci, a jak odbierany jest faktycznie. Bohater transseksualny często doświadcza tragizmu, ponieważ jest rozdarty między ja psychicznym a ja cielesnym, ja wewnętrznym a ja społecznym.

\section{Transseksualność i proces tranzycji ${ }^{55}$. Tragizm podmiotu transseksualnego}

Wewnętrzna cielesność odnosząca się do płciowego wymiaru z reguły odpowiada zewnętrznej egzemplifikacji. Jednak w historie niektórych osób, bohaterów, wpisana jest niezgodność między płcią psychiczną a zewnętrzną

${ }^{52}$ Por. tamże, s. 105, 108.

${ }_{53}$ Tamże, s. 106.

${ }^{54}$ Por. tamże, s. 120. Ciekawym przykładem na przybliżenie poczucia dwoistości: dziewczęcości i chłopięcości jest cykl powieści Andrzeja Czcibora-Piotrowskiego: Rzeczy nienasycone, Cud w Esfahanie, Nigdy dość mirakle.

${ }^{55}$ Proces tranzycji (pojęcie wprowadzone przez Sally Hines), odnosi się do korekty płci. Jest wyjątkowo żmudny i trwa minimum dwa lata. Zaczyna się od wizyt osoby transseksualnej u seksuologa, który najczęściej zostaje lekarzem prowadzącym (por. J. Maj, Przełamujac dychotomię ptci w Polsce. Porównanie sytuacji osób transgenderowych w Polsce, [w:] Postpłciowość? Praktyki i narracje tożsamościowe w ponowoczesnym świecie, red. A.E. Banot, A. Barabasz, R. Majka, Bielsko-Biała 2012, s. 170). Następnie wizyty u psychologa, psychiatry (który podejmuje decyzję o dopuszczeniu do tranzycji), „liczne badania medyczne (endokrynolog, kariotyp, EEG, RTG siodełka tureckiego, badanie dna oka, itp.)” (tamże, s. 170-171 i por. R. Ziemińska, Niezgodność ptci odczuwanej..., s. 80). Kolejny krok to wdrożenie terapii hormonalnej, którą łatwiej jest zmaskulinizować ciało niż dokonać jego feminizacji (por. M.A. Pelczar, dz. cyt., s. 254). Dalsze działania to korekta metrykalna płci i/lub zabiegi chirurgiczne.

Więcej o medycznych aspektach procesu tranzycji w: J. Breska-Kruszewska, D. Rachoń, Medyczne aspekty transptciowości - rozpoznanie i postęowanie lecznicze, [w:] Psycho- 
(często cielesna) reprezentacją i właśnie owa niezgodność, dysforia płciowa jest punktem, w którym rozpoczyna się narracja transseksualisty/transseksualistki.

Podmiot transseksualny zmaga się z doświadczeniem rozbieżności między zewnętrznym ciałem a wewnętrzną (odczuwaną psychicznie) cielesnościa ${ }^{56}$. Ciało rozpatrywane jako kostium, środek techniczny służący do tworzenia relacji z otoczeniem ${ }^{57}$, zaczyna wysyłać (jeszcze w dzieciństwie) fałszywe komunikaty co do tożsamości płciowej ${ }^{58}$. Proces komunikowa-

społeczne, prawne i medyczne aspekty transpłciowości, red. A.M. Kłonkowska, K. Bojarska, Gdańsk 2014; R. Ziemińska, Niezgodność ptci odczuwanej... Natomiast o etiologii transseksualizmu w: M. Fajkowska-Stanik, Transseksualizm i rodzina. Przekaz pokoleniowy wzorców relacyjnych w rodzinach transseksualnych kobiet, Warszawa 2001; J. Bielas, Doświadczenie cielesności. Podmiotowe uwarunkowania transseksualizmu, Kraków 2012, M. Bieńkowska-Ptasznik, Transseksualne doświadczenia ciała, [w:] Corpus delicti rozkoszne ciało. Szkice nie tylko z socjologii ciała, red. E. Banaszak, P. Czajkowski, Warszawa 2010. Z kolei o metrykalnej korekcie płci w: R. Ziemińska, Niezgodność płci odczuwanej...

${ }^{56} \mathrm{~W}$ kulturze euroatlantyckiej doświadczenie, poczucie uwięzienia w nieswoim ciele jest charakterystyczne dla osób transseksualnych. Jacek Bielas w pracy badawczej Doświadczenie cielesności. Podmiotowe uwarunkowania transseksualizmu przywołuje doświadczenia osób transseksualnych, określane przez nie jako: „obcość ciała», «spętanie», «napięcie», "wewnętrzna pustka», "cielesna cisza» lub «uśpienie ciała», a nawet "niemożność zmaterializowania się»" (J. Bielas, Doświadczenie cielesności..., s. 239). Więcej o obcości ciała w doświadczeniu osób transseksualnych w: M. Bieńkowska-Ptasznik, Uwięzieni w obcym ciele - ciało i tożsamość $w$ doświadczeniu osób transseksualnych, [w:] Ucieleśnienia II. Pteć między ciałem i tekstem, red. J. Bator i A. Wieczorkiewicz, Warszawa 2008; taż, Poza binarnym podziatem płci-rzecz o transseksualizmie, [w:] Teatr ptci. Eseje z socjologii gender, red. M. Bieńkowska-Ptasznik, J. Kochanowski, Łódź 2008; taż, Meandry ptci-transseksualizm, [w:] Queer studies. Podręcznik kursu, red. J. Kochanowski, M. Abramowicz, R. Biedroń, Warszawa 2010; taż, Transseksualne doświadczenia..., A.M. Kłonkowska, Pteć: dana..., s. 95.

Badania przeprowadzone przez Elizabeth Boskey w 2014 (na które powołuje się Renata Ziemińska) wskazuja, „że od $0,5 \%$ do $2 \%$ populacji czuje tożsamość transpłciowa, ale tylko od $0,1 \%$ do $0,5 \%$ zdecydowało się na społeczną lub medyczną tranzycję". R. Ziemińska, Niezgodność ptci odczuwanej ..., s. 77.

${ }^{57}$ Por. M. Sarmińska-Górecka, Ciało jako kostium, [w:] Colloquia. Communia. Kobiecość?, red. E. Hyży, Toruń 2008, s. 164.

${ }^{58}$ Dla tożsamości płciowej istotne są trzy aspekty: biologiczny (fizyczne zdeterminowanie płci; efekt genów, hormonów i struktur mózgowych), społeczny (stereotypy płci - zależne od danej kultury - określające, jakie zachowania i cechy uchodzą za kobiece, a jakie za męskie; identyfikacja siebie z innymi osobami z tej samej klasy osób), psychiczny (samoświadomość). Por. K.(R.) Kryszk, Buddyzm a transpłciowość, [w:] Transpłciowość - androgynia, red. A. Kłonkowska, Gdańsk 2012, s. 64; E. Mandal, Pojmowanie fenomenu ptciowości w psychologii, [w:] Zrozumieć płeć. Studia interdyscyplinarne II, red. A. Kuczyńska, E.K. Dzikowska, Wrocław 2004, s. 206; D. Majka-Rostek, Komunikacja genderowa jako komunikacja międzykulturowa, [w:] Zrozumieć płeć. Studia interdyscyplinarne II, red. A. Kuczyńska, E.K. Dzikowska, Wrocław 2004, s. 258; M. Bieńkowska-Ptasznik, Uwięzieni w obcym ciele..., s. 253, R. Ziemińska, Niezgodność ptci odczuwanej..., s. 103. Poszerzone rozumienie tożsamości płciowej znajduje się w Zasadach Yogyakarty (podpisanych przez ekspertów praw człowieka w 2006 roku w Indonezji): „Przez toż- 
nia na opak odbywa się bez jakiejkolwiek winy podmiotu, który sam jest zagubiony w uwierającym kostiumie ciała cywilizowanego, uwikłanego w normy kulturowo-społeczne, stereotypy, narzucajace heteroseksualna matryce i dychotomiczny podział. Dochodzi do przemocy w zakresie spełniania norm przez niechciane ciało, które zmuszone jest do odgrywania cudzej tożsamości płciowej. Narasta potrzeba uzgodnienia płci psychicznej z płcią biologiczna. Wydaje się, że wyjściem z opresji jest proces tranzycji, który daje możliwość osobom transseksualnym rekonstrukcji/scalenia własnej tożsamości płciowej, pozwala na wyrażenie siebie we właściwym ciele (choć nie zawsze pozyskana cielesność odpowiada wcześniejszym wyobrażeniom). Ale jednocześnie tranzycja (w ujęciu medycznym) wikła osoby w dyskurs „nieodpowiedniego ciała” i skutecznie konstruuje model prawidłowej cielesności ${ }^{59}$.

W refleksji nad podmiotem transseksualnym dominuja obecnie perspektywy medyczna oraz socjologiczna, odnoszone do świata pozatekstowego. Natomiast brakuje refleksji tekstologicznej - badania sposobu istnienia zjawiska w tekstach kultury. Celem podjętych rozważań jest zapełnienie tej luki.

Jednak najpierw warto zastanowić się, z jakich powodów dominuje ujęcie medyczne transseksualizmu. Czym można tłumaczyć pragnienie osób transseksualnych poddania się operacjom? Odpowiedzi na postawione pytania należy szukać w kulturze, społeczeństwie i jego socjalizacji. Tam, gdzie dominuje binarny kod płci, tam, gdzie płcie kulturowe (męska, żeńska) zespolone sa z płciami biologicznymi, bez możliwości zmiany, pojawia się presja (w obawie przed wykluczeniem) wpasowania się w owe matryce, schematy. W kulturze euroatlantyckiej obserwujemy dążenie osób transseksualnych do operacyjnej korekty płci, natomiast w innych kulturach takiego dążenia raczej nie $\mathrm{ma}^{60}$. Uwzględniająca powyższe hipoteza przedstawiona przez Małgorzatę Bieńkowską-Ptasznik: „Mogłoby się wręcz wydawać, że gdybyśmy jako społeczeństwo nie przywiązali wagi do ciała, transseksualizm by nie istniał. Ciało bowiem lokuje transseksualistów w przestrzeni społecznej”61 ma rację bytu. Jednak (zresztą jak badaczka zauważa) spo-

samość płciową należy rozumieć głęboko odczuwane wewnętrzne i indywidualne doświadczenie własnej płci, które odpowiada lub nie płci metrykalnej, włączając w to osobiste odczucie własnego ciała (które może prowadzić do modyfikacji wyglądu zewnętrznego lub biologicznych funkcji metodami medycznymi, chirurgicznymi lub innymi) i inne formy wyrażania własnej płci przez ubiór, mowę czy sposób zachowania", [w:] R. Ziemińska, Niezgodność ptci odczuwanej..., s. 79.

${ }^{59}$ Por. J. Halberstam, Transgender butch: butch/FTM border wars and the masculine continuum, [w:] Female Masculinity, Durham, London 2018, s. 143, 162.

${ }^{60}$ Por. M. Bieńkowska-Ptasznik, Poza binarnym podziatem..., s. 199.

${ }^{61}$ Taż, Dylematy badacza - wybrane niuanse z badań nad transseksualizmem, [w:] Kalejdoskop genderowy. W drodze do poznania płci społeczno-kulturowej w Polsce, red. K. Slany, B. Kowalska, M. Ślusarczyk, Kraków 2011, s. 468. 
łeczeństwo zachodnie bardzo silnie przywiązane jest do dychotomicznego podziału płciowego i do wpisywania w nie ciała. Wydaje się, że rozwiązaniem mogłoby być nie negowanie kategoryzacji płciowej, a raczej odrzucenie samego binarnego podziału i wprowadzenie opcji tożsamości niebinarnej ${ }^{62}$. Ale dyskurs, społeczeństwo narzuca kulturowe definicje męskości, kobiecości, stosując (jakby od niechcenia, mimowolnie, pozornie wynikająca z natury) przemoc normalizacyjną ${ }^{63}$, w której kluczową rolę odgrywa cisnorma ${ }^{64}$. Mamy sprostać oczekiwaniom społecznym, które w ramach socjalizacji, a również przez mechanizm powtarzania, cytowania określonych zachowań, emanacji powierzchowności, wydaja się oczywiste. Stąd obcość w postrzeganiu przez osoby transseksualne własnego ciała, które nie współgra z odczuwaną przez nie płcią, można (moim zdaniem) rozpatrywać jako wdrukowaną przez system kontroli społecznej nienawiść. To samo zagadnienie wolno wszakże analizować zupełnie inaczej (jak to uczynił Jay Prosser), wskazując, że jedną z dróg uwolnienia się od cierpienia przez osoby transseksualne są operacje, które pozwalają na istnienie zgodnie z płcią (jednoznaczną kategoryzacja), która po prostu czuja; pragna tej, a nie innej tożsamości, potrzebuja jednoznacznej identyfikacji ${ }^{65}$. Zatem nie bycie pomiędzy, nie funkcjonowanie poza kategoriami męskości i kobiecości w społeczeństwie, w którym owe kategorie sa podstawowe, pozwoli na istnienie; wręcz przeciwnie. Tym samym rozważanie transseksualności z perspektywy queer może (choć nie musi) być bezcelowe. Osoby transseksualne zwykle potrzebuja społecznego potwierdzenia odpowiednio swojej docelowej kobiecości, męskości. W rezultacie często koncentrują się na swoim wizerunku, zachowaniu i gestach, co może przeobrazić się w samokontrolę. Mimo to pozyskanie społecznej akceptacji pozostaje istotnym elementem $\mathrm{w}$ budowaniu i uzewnętrznianiu swojej tożsamości. Biorąc pod uwagę powyższe, źródeł transseksualizmu można upatrywać $\mathrm{w}$ tym, co wewnętrzne, a więc w niedopasowaniu płci psychicznej do ciała, albo w tym, co zewnętrzne: w porządku społecznym, który nie dopuszcza innych tożsamości niż kobieca

${ }^{62}$ Por. R. Ziemińska, Niebinarne i wielowarstwowe pojęcie ptci, [w:] Niebinarne i wielowarstwowe pojęcie ptci..., s. 130 i taż, Niezgodność płci odczuwanej..., s. 92.

${ }^{63}$ Por. M.A. Pelczar, Co $i$ kto nie „przechodzi”..., s. 251.

${ }^{64}$ Cisnorma, czyli przekonanie, że normą jest tożsamość płciowa zgodna z płcią przypisana po urodzeniu (płcią biologiczna). Por. M. Rzeczkowski, Trans-optymista, wybór tekstów, [w:] Psychospołeczne, prawne i medyczne aspekty transptciowości, red. A.M. Kłonkowska, K. Bojarska, Gdańsk 2014, s. 17; M. Bieńkowska, Transseksualność w badaniach spotecznych-aspekt teoretyczny i metodologiczny, [w:] Psychospołeczne, prawne i medyczne aspekty..., s. 93.

${ }^{65}$ Por. J. Prosser, Second Skins. The Body Narratives of Transsexuality, New York 1998, s. $72,85$. 
i męska ${ }^{66}$. Oczywiście takie perspektywy stwarzają dylematy co do rozpatrywania płciowości osób transseksualnych, bowiem transseksualność z jednej strony można rozważać jako genderową transgresję, z drugiej zaś jako genderowy konserwatyzm. Zatem jakie przyjąć stanowisko? Czy należy stworzyć spójna teorię, czy pozwolić na teoretyczne rozproszenie i wieloznaczność? Drugie rozwiązanie, traktujące o wieloznaczności, wydaje się nie tylko bardziej kuszacce, ale przede wszystkim bardziej racjonalne, wsłuchujące się w narracje osób transseksualnych czy też cispłciowych o transseksualnych. Pewną próbkę przyjętego stanowiska stanowią poniższe fragmenty egodokumentów i wywiadów.

Kinga Kosińska (trans kobieta) rozpoczyna autobiografię zatytułowaną Brudny róż. Zapiski z życia, którego nie było od opisu swojej cielesności, której nie akceptuje:

Gruba warstwa pudru, zbyt pomarańczowego, a pod nią zarost, choć przecież goliłam się rano przed wyjściem. I ta sztuczna wyniosłość maskująca ból ${ }^{67}$;

Nie wyobrażałam sobie siebie jako dorosłego mężczyzny, którym w jakimś sensie już byłam [...]. Gdy mama chciała iść ze mną na zakupy, sprawić mi jakąś męską garderobę, było to dla mnie tortura ${ }^{68}$.

Z kolei Daniel Zamojski (trans mężczyzna) w Aleksandra Zamojska jest mężczyznq wspomina po operacji rekonstrukcji klatki piersiowej:

Byłem przygotowany na trzy operacje, a tymczasem zanosi się na więcej. Skąd na to brać pieniądze, jak wytrzymać kolejne narkozy? Boję się Nika... Ale wyobraź sobie, że choć efekty są nie takie, jakich oczekiwałem, w całym tym bólu potrafię być szczęśliwy, bo jestem mimo wszystko coraz bliżej celu, celu bycia fizycznie mężczyzna ${ }^{69}$.

Zupełnie inny ogląd siebie prezentuje Wiktor Dynarski:

wgryzłem się w teorię queer i podejście transgenderowe. Widzę stereotypy i nie chcę być stereotypem. Przeszedłem przez etap stereotypów, ale głównie ze względu na swojego lekarza, żeby wyglądać bardziej przekonywająco ${ }^{70}$;

Wierzę, że każda osoba czuje, jakie charakterystyki są jej przynależne. Większość ludzi identyfikuje się z byciem mężczyzną lub kobietą. Ja używam terminu transmężczyzna, ponieważ nie czuję się aż tak silnej przynależności do kategorii męż-

${ }^{66}$ Por. M. Dębińska, Queer i polityka cierpienia. Strategie narracyjne i polityczne osób trans $w$ Polsce, [w:] Strategie queer. Od teorii do praktyki, red. M. Kłosowska, M. Drozdowski, A. Stasińska, Warszawa 2012, s. 241.

${ }^{67}$ K. Kosińska, Brudny róż. Zapiski z życia, którego nie było, Warszawa 2015, s. 5.

${ }^{68}$ Tamże, s. 27.

${ }^{69}$ D. Zamojski, Aleksandra Zamojska jest mężczyzna, Warszawa 2005, s. 99.

${ }^{70}$ Wywiad z Wiktorem Dynarskim, przeprowadzony przez Piotra Pacewicza, Wszyscy jesteśmy trans, [w:] Zakazane miłości, red. M. Konarzewska, P. Pacewicz, Warszawa 2008, s. $194-195$. 
czyzn rozumianych jako biologiczno-fizyczny stereotyp. Chciałem zmienić pewne właściwości swego ciała i to, jak jestem postrzegany. Udało się. Skorygowałem to, co uważałem za konieczne ${ }^{71}$.

Przywołane fragmenty obrazuja, że nie ma jednego typu transseksualności i definicja transseksualności powinna być niedomknięta.

Jednak ciagle pozostaje problem zdefiniowania płci. Jeśli uznać, że płeć jest istotna dla osób transseksualnych, to jak ją rozpatrywać? Słynne słowa Simone de Beauvoir „Nie rodzimy się kobietami, stajemy się nimi”" moga, moim zdaniem, w zaskakujacy sposób okazać się pomocne. Wprowadzony przez de Beauvoir podział na płeć biologiczna (sex) i na płeć społeczno-kulturową (gender) został podważony przez Judith Butler i przedstawiony jako złudzenie. Butler w pracy Uwikłani w płeć, wychodzac od zdania mentorki drugiej fali feminizmu, stwierdza: „[...] biologiczna płeć nie może być przeddyskursywnym faktem anatomicznym. [...] biologiczna płeć jest zawsze z definicji kulturowa płcią"73. Zatem podział między kobietą a mężczyzna wynika z różnic społecznych, a nie anatomii, a materializacja ciała dokonuje się przez język, w wyniku dyskursu, powtarzania i cytowania norm związanych ze społecznym wyobrażeniem (w konkretnej kulturze) bycia kobieta, mężczyzna. Jeśli płeć biologiczna ,zawsze jest sytuowana jako mimetyczne odbicie zawartości semantycznej płci kulturowej”" to to według Butler ciało jest kulturowym konstruktem. Nie chodzi tu o zanegowanie różnicy płci w ogóle, a raczej o wskazanie, że zawsze mamy do czynienia z jej kulturowym ujęciem, kulturową interpretacja ${ }^{75}$.

Do tego samego zdania odnosi się Jay Prosser, który sam przeszedł proces tranzycji, pisząc w Second Skins. The Body Narratives of Transsexuality:

W kontekście transseksualnej trajektorii w istocie epigram de Beauvoir może być czytany bardzo różnie, opisując nie ogólne pojęcie płci kulturowej jako radykalnej performatywności, ale jako charakterystycznej narracji (w tym wypadku) m/K, walki w kierunku upłciowionego ucieleśnienia. Nikt nie rodzi się kobieta, niemniej jednak może się nią stać - pod wpływem medycznych interwencji, osobistej wytrwałości, ekonomicznego bezpieczeństwa, społecznego wsparcia itp.: stanie się kobieta, mimo że nie jest nią od urodzenia, może być postrzegane jako główny cel. W tej reprezentacji płci biologicznej jako obrazowy efekt performansu praca Uwikłani w płeć nie może wyjaśniać transseksualnego pragnienia upłciowienia cielesności jako telos. W związu z tym Uwiktani w pteć dają podpowiedź, jak odczytywać transseksualne

${ }^{71}$ Tamże, s. 198.

${ }^{72}$ S. de Beauvoir, Druga płeć, tłum. G. Mycielska, M. Leśniewska, J. Sutorski i spółka, Warszawa 2007, s. 299.

${ }^{73}$ J. Butler, Uwiktani w płeć, tłum. K. Krasuska, Warszawa 2008, s. 55.

${ }^{74}$ A. Buczkowski, Reprodukowanie ciała uptciowionego, [w:] Społeczne tworzenie ciała. Pteć kulturowa i pteć biologiczna, Kraków 2005, s. 215.

${ }^{75}$ Por. J. Mizielińska, (De)Konstrukcje kobiecości, Gdańsk 2004, s. 189. 
podmioty, których cielesne trajektorie moga przekroczyć strukturę teorii performatywności płci kulturowej ${ }^{76}$.

Analogiczne stanowisko w sprawie płci biologicznej i procesu materializacji ciała zajmuje Michael Kimmel, który stwierdza: „[...] jednostki transpłciowe sprawiaja, że ich płeć biologiczna emanuje z ich tożsamości płciowej, podczas gdy w powszechnej opinii tożsamość płciowa musi emanować z płci biologicznej"77. Przyjęta przez Prossera i Kimmela perspektywa nie jest oczywiście powrotem do XIX-wiecznego esencjalizmu i polaryzacji płci ze względu na biologię, wręcz przeciwnie, wskazuje na ważność tożsamości płciowej (w jej psychicznym i społecznym wymiarze) w rekonstruowaniu cielesności (płci biologicznej), ale jednocześnie nie sprowadza człowieka i jego płci do jedynie performatywnych, opresyjnych praktyk.

Prosser zaznacza, że cielesność jest ważna w identyfikowaniu siebie, a proces tranzycji (ze względu na ukonstytuowanie podmiotu) jest narracja sensowną ${ }^{78}$. Jednocześnie rozważania nad transseksualnościa podają w wątpliwość pewne rozpoznania teorii queer, która neguje istnienie granic i choć wydaje się, że stała się ochronnym parasolem dla podmiotów z LGBTQ, to w przypadku osób transseksualnych (aczkolwiek trzeba zaznaczyć - nie wszystkich) okazała się niefunkcjonalna ze względu na tak dalekie odejście od tożsamości, podmiotowości i ich dekonstrukcję ${ }^{79}$. Niewątpliwie nie ma jednego właściwego i uniwersalnego dla wszystkich sposobu postrzegania płci i ciała. Tym bardziej, że wiele trans kobiet po procesie tranzycji nie jest odbieranych jako cispłciowe kobiety, a cielesność wielu trans mężczyzn jest wieloznaczna ${ }^{80}$. Niektóre $z$ osób transseksualnych nie moga ze względów finansowych lub zdrowotnych poddać się wszystkim operacjom, inne zaś nie

${ }^{76}$ J. Prosser, dz. cyt., s. 33. "In the context of the transsexual trajectory, in fact, Beauvoir's epigram can be read quite differently as describing not a generic notion of gender's radical performativity but the specific narrative of (in this case) the male-to-female transsexual's struggle toward sexed embodiment. One is not born a woman, but nevertheless may become one - given substantial medical intervention, personal tenacity, economic security, social support, and so on: becoming woman, in spite of not being born one, may be seen as a crucial goal. In its representations of sex as a figurative effect of straight gender's constative performance, Gender Trouble cannot account for a transsexual desire for sexed embodiment as telos. In this regard Gender Trouble serves to prompt readings of transsexual subjects whose bodily trajectories might exceed its framework of the theory of gender performativity" (tłumaczenie własne).

${ }^{77}$ M. Kimmel, Genderowie ciało, [w:] Społeczeństwo genderowe, red. A.M. Kłonkowska, tłum. A. Czerniak, A.M. Kłonkowska, Gdańsk 2015, s. 461.

${ }^{78}$ Por. J. Prosser, dz. cyt., s. 59, 83.

${ }^{79} \mathrm{Z}$ kolei teoretycy queer krytykują koncepcję tożsamości jako narzędzia władzy. Por. M. Rogowska-Stangret, dz. cyt., s. 319.

${ }^{80}$ Por. J. Halberstam, dz. cyt., s. 163-164. 
definiują swojej transseksualności ze względu na silne pożądanie penisa lub waginy i mogą doświadczyć silniejszego pragnienia bycia trans lub queer niż bycia mężczyzną lub kobieta. Jednak niezgodność płciową i proces tranzycji dla osób o jednoznacznym lub dominującym poczuciu przynależności płciowej należy raczej rozważać jako problem egzystencjalny dotyczący cielesności i jej trajektorii, tragizmu wynikającego z poczucia braku spójnej tożsamości związanej z płcią (jako kategorią społeczną i atrybutem osobowości) oraz odrzucenia społecznego (braku zrozumienia). Proces tranzycji z reguły poprzedzony jest ujawnieniem bohatera w zakresie odczuwanej płci, często jednak wyznanie spotyka się z brakiem akceptacji społecznej, zaś efekty procesu tranzycji mogą być boleśnie podważone przez zewnętrzna publikę. Stąd sytuacja tragiczna tego typu bohatera, który tym bardziej zasługuje na pogłębioną refleksję. Poza tym problem transseksualności wpisuje się w szersze zagadnienie ustalenia i określenia własnej tożsamości.

\section{Tekstualizacja podmiotu transseksualnego}

Jak dowodzi Małgorzata Czarnocka, emocje nie są odseparowane od rozumu, stany biologiczne wpływają na stany świadomości, i odwrotnie, stany umysłowe oddziałuja na stany somatyczne, a praktyczna strona życia, jej przejawy polityczne, ideologiczne, splata się ze stroną poznawczą ${ }^{81}$. Afirmacja ciała skorelowanego z psychika, z przeżywaniem świata znajduje swoje miejsce w fenomenologii Maurice'a Merleau-Ponty'ego. Oto psychika nie jest ukryta w ciele, ale odnajduje wyraz w geście, ruchach czy słowie ${ }^{82}$. Mieć ciało to dla filozofa wiązać się z określonym środowiskiem, utożsamiać się z pewnymi projektami, realizować pewne zachowania ${ }^{83}$. Co więcej, zasoby własnego ciała można w pewien sposób rozbudowywać, oswajając przedmioty pochodzace z zewnątrz. Na przykład laska czy kapelusz przez kontakt z ciałem niejako poszerzają jego zakres i równocześnie pozwalaja na poznanie/posiadanie świata, zarówno w sensie biologicznym, jak i kulturowym. Merleau-Ponty wskazuje na dwuznaczność egzystencji, w której zachodzi komunikacja między tym, co cielesne, a tym, co umysłowe czy psychiczne. Granice między nimi zacierają się. „Każde wydarzenie cielesne ma znaczenie psychiczne i na odwrót - ciało stanowi ekspresję psychiczności”" ${ }^{4}$. Koncepcję Merleau-Ponty'ego można odnieść do odczucia tęsknoty

${ }^{81}$ Por. M. Czarnocka, Podmiot poznania a nauka, Toruń 2012, s. 311-312.

${ }^{82}$ Por. J. Trzódek, Na tropach podmiotu. Między filozoficznym a empirycznym ujęciem podmiotowości, Kraków 2013, s. 55.

${ }^{83}$ Por. tamże, s. 58, 59-60.

${ }^{84}$ Tamże, s. 60. 
transseksualistek i transseksualistów za przeżywaniem ciała jako swojego, jako „ciała-ja”, stąd tak istotne w trakcie procesu tranzycji rekwizyty, takie jak: wypchany silikonowymi wkładkami stanik imitujacy piersi (na przykład w filmie Agnieszki Holland Historia Gwen Arauja); peruka (w filmach: Telenowela Pernille Fischer Christensen, Dziewczyna $z$ portretu Toma Hoopera, Witaj w klubie Jean-Marca Vallée, TransAkcja Sławomira Grünberga i Katki Reszke); bandaż, elastyczna podkoszulka niwelujące piersi (na przykład w Coby w reż. Christiana Sondereggera, Nie czas na tzy w reż. Kimberly Peirce); włożone do spodni w miejsce krocza zwinięte skarpetki, dajace złudzenie penisa (na przykład w filmie Nie czas na łzy). Protezy ciała pozwalają na zaistnienie ucieleśnionej świadomości, która wszakże poddana jest społecznej presji.

Twórców między innymi literatury i filmu ciagle fascynuje zgłębianie świata człowieczego. Jak przedstawiany jest człowiek? W jaki sposób funkcjonuje w świecie literackim i filmowym? Za pomoca jakich środków wyrazu teksty kultury włączają się w dyskurs o człowieku? Literatura i film niejako wcielają się w przedstawianą rzeczywistość ludzka, symulująa, przywołują w sposób quasi-dokumentarny ${ }^{85}$. Ukazując losy indywidualnych bohaterów, zwykle odsłaniają znaczenia, które wykraczaja poza jednostkowe postaci i wyznaczają szerszą perspektywę oglądu, poznania podmiotu - również transseksualnego.

I tak na przykład można dostrzec wyraźne podobieństwo między fikcyjną transbohaterką Sofią z powieści Johanny Nilsson Kochajacy na marginesie a Kingą Kosińska, autorką autobiografii Brudny róż. Zapiski z życia, którego nie było. Paralelne historie przeżywają również na przykład trans kobiety z dokumentalnego filmu Karoliny Bielawskiej Mów mi Marianna (Polska 2015) oraz z filmu fabularnego Normalny (USA 2003) w reżyserii Jane Anderson. Obie bohaterki podejmują trud procesu tranzycji, mimo że wcześniej funkcjonowały w życiu społecznym w roli mężów, ojców. Oczywiście kluczowy dla literackiego i filmowego przybliżenia historii jest sposób, pomysł na sportretowanie transseksualnych bohaterów. $\mathrm{Z}$ reguły są to postaci wieloznaczne ze względu na funkcje, jakie pełnią w dyskursie. Sa one obiektami, „o których się mówi”, jednostkami kompozycji, złożonymi figurami, „którymi się mówi” i figurami „które mówia”" ${ }^{6}$. Postacie - poprzez poetykę i styl - artykułują indywidualne i zbiorowe uświadomienia, przeżycia, doświadczenia ${ }^{87}$. Zarazem uosabiają ich ponadjednostkowe, powtarzalne

${ }^{85}$ Por. E. Kasperski, Świat człowieczy. Wstęp do antropologii literatury, Pułtusk-Warszawa 2006, s. 110, 111.

${ }^{86}$ Por. tamże, s. 26.

${ }^{87}$ Por. tamże, s. 36. 
matryce i modele. Opowieści zwykle budowane są w sposób linearny: od dzieciństwa do korekty płci, posługują się retrospekcjami, czasami również dokonują podsumowania oraz całościowego oglądu przebytego procesu tranzycji. Natomiast z uwagi na różnorodność przeżyć, zdarzeń sytuujących się w podobnych hasłach wywoławczych: niezgodność płciowa, proces tranzycji, korekta płci powielaja pewną matrycę ${ }^{88}$, ale równocześnie są nietuzinkowe i dla badacza moga być fascynujące ze względu na uchwycenie zmagań, procesu scalania się człowieka.

Prosser w Second Skins. The Body Narratives of Transsexuality, analizując historie zapisane w autobiografiach, koncentruje się na korelacji ciała i narracji. Narrację ujmuje jako sposób opowiadania o sobie i jako rodzaj drugiej skóry (,Narrative is also a kind of second skin”) ${ }^{89}$. Z kolei przyjęta przeze mnie perspektywa badawcza, która również dotyczy trajektorii narracji i ciała transseksualnego podmiotu, ujmuje proces tranzycji bardziej jako pisanie, a właściwie czytanie i pisanie (czytanie, pisanie, czytanie) siebie przez siebie i innych. Stąd propozycja określania: ciałopisanie.

$\mathrm{W}$ opublikowanych i zarejestrowanych zwierzeniach w autobiografiach trans kobiet i trans mężczyzn pojawiają się odniesienia do hipotekstów, na przykład Kinga Kosińska w Brudnym różu. Zapiskach z życia, którego nie byto wspomina:

Podobnie miałam z Virginią Woolf. Obejrzałam Godziny z Nicole Kidman i się zaczęło. Pani Dalloway, Orlando, Fale. Życie nabrało innego wymiaru. Tak to czułam ${ }^{90}$.

Spotkania z obrazami literackimi i filmowymi tworzą wewnętrzne biblioteki, filmoteki, a przefiltrowane przez własne doznania pozwalają na subiektywne zapamiętanie przez odbiorcę takich fragmentów, obrazów, które związane są z jego tożsamościa, a w przypadku osób transseksualnych silniej $\mathrm{z}$ własną tożsamością płciową. Bohaterowie, próbując uzewnętrznić swoją tożsamość, poszukują hipotekstów, w których mogą odnaleźć potwierdzenie swojej tożsamości, racji istnienia. Kreują siebie przez ciałopisanie. Z jednej strony ich somatyczność staje się tekstem, tekstualizują siebie, z drugiej zaś część bohaterów tworzy tekstowe narracje o sobie w prozie dokumentalnej. Pragna zaistnieć społecznie poprzez tekst. W tym kontekście dochodzi do nakładania niezgodności płciowej i procesu tranzycji na tekstualizację podmiotowości.

${ }^{88}$ Więcej o powtarzalności, pewnej schematyczności w narracjach osób transseksualnych w: S. Faludi, W ciemni, tłum. J. Bednarek, Warszawa 2017, s. 140-143, 311-312.

${ }^{89}$ J. Prosser, dz. cyt., s. 101.

${ }^{90}$ K. Kosińska, dz. cyt., s. 98. O znaczeniu Pani Dalloway V. Woolf dla Kingi Kosińskiej pisałam w: A. Kujawska-Kot, Literackie odpowiedzi na konstelacje obcości i inności, [w:] Kultury obcości, red. M. Jedliński, K. Witczak, Bydgoszcz 2016, s. 64-77. 
Do tej pory powstałe prace, oprócz nielicznych wyjątków, na przykład Jay Prosser Second Skins: The Body Narratives of Transsexuality, Niall Richardson Transgressive Bodies. Representations in Films and Popular Culture (część III: Transsexed Bodies), Susan Faludi W ciemni (fragmenty), Jack Halberstam Female Masculinity (rozdział: Transgender Butch: Butch/ FTM Border Wars and the Masculine Continuum), Aleksandra Migalska Transseksualna opowieść o władzy, czyli czego nie wiemy o kobiecości $i^{91}$ koncentrowały się na ujęciu medycznym, psychologicznym i socjologicznym. Zatem istnieje potrzeba wprowadzenia problematyki transseksualności $\mathrm{w}$ dyskurs literaturoznawczy i filmoznawczy. Kluczowe dla wspomnianych dyskursów sa narzędzia literaturoznawcze (terminy, pojęcia, kategorie), które pozwalają dostrzec intertekstualność transpłciowego podmiotu jako bytu tekstowego. Transseksualistki/transseksualiści, uzewnętrzniając swoją kobiecość/męskość, odwołują się nie tylko do wcześniejszych obserwacji kobiet/mężczyzn, ale również powołują się na liczne hipoteksty. Odniesienia do hipotekstów można odnaleźć w literaturze zarówno dokumentalnej ${ }^{92}$, jak i fikcjonalnej ${ }^{93}$, w filmie dokumentalnym ${ }^{94}$ i fabularnym ${ }^{95}$, a także w relacjach osób transseksualnych. Jednak do tej pory rola intertekstualności ${ }^{96}$ w kształtowaniu tożsamości płciowej u trans kobiet/trans mężczyzn nie została zbadana. Proponuję wypełnić tę lukę, koncentrując się na wzorcach, do

${ }^{91}$ Artykuł zamieszczony jest w: Kalejdoskop genderowy. W drodze do poznania płci społeczno-kulturowej w Polsce, red. K. Slany, B. Kowalska, M. Ślusarczyk, Kraków 2011.

${ }^{92}$ Na przykład Anna Grodzka w mam na imię Ania przywołuje istotne w uzewnętrznieniu tożsamości płciowej hipoteksty: Tajemniczy ogród F.H. Burnett, Zabić drozda H. Lee, Wymarzony dom Ani L.M. Montgomery, Świat wedtug Garpa J. Irvinga. Analizą i interpretacją przywołanych hipotekstów w kontekście uzewnętrznienia tożsamości płciowej przez Grodzką zajmowałam się w: A. Kujawska-Kot, Intertekstualny wymiar kobiecości w odniesieniu do osób transpłciowych, [w:] Tożsamość. Kultura. Nowoczesność t. 1, red. B. Morzyńska-Wrzosek, M. Kurkiewicz, I. Szczukowski, Bydgoszcz 2017, s. 296-312.

${ }^{93}$ Zob. panna Frost (trans kobieta), bohaterka powieści Johna Irvinga W jednej osobie odnajduje potwierdzenie swojej kobiecości, grając role kobiece w sztukach Ibsena: Hedda Gabler, Dom lalki, Dzika kaczka (por. J. Irving, W jednej osobie, tłum. M. Moltzan-Małkowska, Warszawa 2012, s. 248-249, 110).

${ }^{94}$ Dla Marii Jose, transbohaterki filmu Dziewczyny z wyboru Kaitona Kalatzidis wzorem w kreowaniu własnej osoby stała się Rita Hayworth.

${ }^{95}$ Zob. Veronica (transseksualistka) z filmu Telenowela namiętnie ogląda serial, prawdopodobnie utożsamiając się z kobiecymi bohaterkami z telenoweli (dostrzegamy jej wzruszenie podczas seansów).

${ }^{96}$ Intertekstualność ujmuję zgodnie z jej klasyczną odsłoną: w tekście obecne są sygnały intertekstualne (jednokierunkowe), które „służą modelowaniu znaczeń tekstowych, a przywołania (odwołujące się do pamięci czytelnika) tworzą kontekst interpretacyjny”. E. Szczęsna, Technologie cyfrowe i humanistyka - wzajemne relacje, [w:] Nowa humanistyka. Zajmowanie pozycji, negocjowanie autonomii, red. P. Czapliński, R. Nycz, D. Antonik, J. Bednarek, A. Dauksza, J. Misun, Warszawa 2017, s. 413-414. 
których odnoszą się/odnosiły się osoby transseksualne; wzorcach przypominających nici do utkania własnej, ale przenicowanej przez różne stereotypy, konwencje plecionki złożonej z choreografii własnego ciała: ruchów, gestów, mimiki, sposobów chodzenia, ozdabiania, wyboru garderoby, perfum oraz języka: sposobu prowadzenia rozmów, ekspresji fonii, a jeszcze wcześniej upłciowienia języka przez odpowiedni rodzaj gramatyczny i prowadzenie wewnętrznego dyskursu. Badając teksty i przedstawiony w nich proces transformacji, warto skoncentrować się na przywołanych przez bohaterów innych tekstach kultury, które przyczyniły się do ujawnienia prawdziwego głosu wewnętrznej płci i zobrazowania niezgodności płciowej i poszczególnych etapów procesu tranzycji (jako doświadczenia i równocześnie kreacji doświadczenia). Dla bohaterów ważna rolę odgrywają wizerunki aktorek, pisarek czy miss wpisane w kontekst kulturowy oraz istotne sa te hipoteksty, w których mogą odnaleźć potwierdzenie swojej tożsamości, racji istnienia. Tym samym uzewnętrzniając swoją kobiecość/męskość, uruchamiają następujące relacje intertekstualne: tekst - tekst, tekst - gatunek, tekst - rzeczywistośs ${ }^{97}$. Na przykład w Mirażach Sylwii Zientek Julian (doświadczający niezgodności płciowej) jest zafascynowany postacią Marleny Dietrich w męskim ubraniu z filmu Marocco Josefa von Sternberga (USA 1930), a scena pocałunku Dietrich z inną kobietą szczególnie go ekscytuje ${ }^{98}$. Amy Jolly, artystka wodewilowa - w którą wciela się Dietrich - bawiąc się swoim wizerunkiem, kreuje siebie na mężczyznę, zakładając frak i cylinder. Ale autokreacja Jolly podsycona zostaje złożeniem pocałunku na ustach kobiety siedzącej przy stoliku, przynależącej zatem do widowni. Julianowi bliska jest również postać Marii Rodziewiczówny, noszącej męską garderobę z krótko przystrzyżonymi włosami ${ }^{99}$. Z kolei Nong Toom z Pięknego boksera (Tajlandia 2004), filmu opartego na prawdziwych wydarzeniach w reżyserii Ekachaia Uekrongthama, wzrusza się, śledząc na szklanym ekranie wybory miss. Bokser wraz z innymi uczestnikami zawodów stoi na ulicy i ogląda przez szybę rywalizację o tytuł Królowej Północy. Gdy pada werdykt i modelka płacze, on również nie może powstrzymać łez, co więcej, projektuje na obraz telewizyjny swój wizerunek, ale w wersji kobiecej. W jego projekcji to panna Toom Parinya z Chiang Mai otrzymuje tytuł królowej piękności. Finalnie bokser widzi siebie w czerwono-żółtym stroju, mocnym makija$\dot{z} u$, w koku i wpiętym weń kwiatem. Przedstawienie pragnienia bohatera, który przekracza ramę ekranu, można powiązać z koncepcją zewnętrzne-

${ }^{97}$ Por. R. Nycz, Intertekstualność i jej zakresy: teksty, gatunki, światy, [w:] Między tekstami: Intertekstualność jako problem poetyki historycznej: studia, red. J. Ziomek, J. Sławiński, W. Bolecki, Warszawa 1992, s. 16-29.

${ }^{98}$ Por. S. Zientak, Miraże, Warszawa 2015, s. 148.

${ }^{99}$ Por. tamże, s. $183-184$. 
go i wewnętrznego punktu widzenia Borisa Uspienskiego ${ }^{100}$. Biorąc pod uwagę perspektywę bohatera i to, w jaki sposób doświadcza telewizyjnego obrazu, warto przyjać tezę o obserwacji (śledzeniu) przez niego wyborów miss z dwóch punktów widzenia. Początkowo Toom patrzy z zewnętrznego punktu widzenia, a więc widzi ramę obrazu (obudowę telewizora), następnie wkracza w świat przedstawiony, co więcej, przekształca go, stając się królową piękności. Zatem ekran, emitowany obraz staje się dla bohatera miejscem ucieczki, które daje schronienie, ponieważ można go przez własną projekcję (marzenie) przetworzyć. Ciało Tooma (widza) współdziała z ogladanym programem telewizyjnym. Jak przekonuje włoski reżyser i semiotyk Gianfranco Bettetini

odbiorca pobudzony sensorycznie [...] wprawia w ruch swoją aktywność psychiczna, przekształca własną fizyczność w niematerialną formę symboliczna, w ślady ukierunkowane, zorientowane na podmiot już tu wcześniej obecny. Ciało widza „rozciąga się” więc, tworzac jak gdyby „inną naturę”.

Włoski teoretyk tak pojmowane ciało widza nazywa ,protezą symboliczną". Proteza jest to, jak powszechnie wiadomo, aparat sztucznie stworzony i zastępujący lub uzupełniający brakującą część ciała. W interesującym nas przypadku komunikacji filmowej chodzi o zastapienie całej materialności ludzkiego ciała. Proteza symboliczna jednak nie tylko zastępuje brakujące ciało, ale w ogólniejszym znaczeniu - jest aparatem, który poszerza promień działania organów fizycznych tak, jak czynią to na przykład megafon, soczewka i peryskop. W ten sposób proteza symboliczna może również penetrować miejsca wyłączone z możliwości jej naturalnego oddziaływania, ale ograniczone możliwościami „języka filmu”101.

Zatem można przyjąć hipotezę, że część z bohaterów transseksualnych (zarówno z tekstów fikcjonalnych, jak i dokumentalnych) niemal intuicyjnie lgnie do obrazu filmowego, nie tylko przez istniejące w nich wzorce kobiecości/męskości, ale również przez specyfikę doznań widza.

Dla innej transbohaterki z egodokumentu $W$ ciemni Susan Faludi istotnym obrazem filmowym jest Kolacja o ósmej (USA 1933) George'a Cukora. Stefánie Faludi (zgodnie z relacją córki) oglądała ten film co najmniej raz do roku (funkcjonując jeszcze w roli męskiej jako Steven ${ }^{102}$ ). Była zauroczona przede wszystkim scena, w której pojawiała się służąca dziewczyny

${ }^{100}$ Por. B. Uspienski, Strukturalna wspólnota różnych sztuk. Ogólne zasady organizacji dzieta malarskiego i literackiego, [w:] Poetyka kompozycji: struktura tekstu artystycznego i typologia form kompozycji, tłum. P. Fast, Katowice 1997, s. 191-199.

${ }^{101}$ Bettetiniego referuje Tadeusz Miczka w: T. Miczka, Cielesny aspekt podmiotowości w kinie, [w:] Kino: Gest - Ciało - Ruch. Film w perspektywie systemów komunikowania niewerbalnego, red. A. Gwóźdź, Wrocław 1990, s. 131.

${ }^{102}$ Por. S. Faludi, dz. cyt., s. 121-122. 
z rewii „wystrojona w osobliwą wersję pokojówki, z aksamitno-koronkowym stroikiem na głowę i falbaniastym fartuszkiem z ogromna kokardą"103. Stefánie zamówiła wykonanie repliki kostiumu, aby następnie w nim się sfotografować. Taka wersja kobiecości była dla Stefánie pożądana, a o jej osobliwym guście moga również świadczyć rubinowe trzewiki, zakładane przez nią na specjalne okazje ${ }^{104}$. Aluzja do pantofelków Dorotki z musicalu Czarnoksiężnik z Krainy Oz (USA 1939) staje się wyraźna, bowiem sama bohaterka wskazuje na film Victora Fleminga, odczytując swojej córce zaświadczenie od lekarza (po medycznej korekcie płci):

- Mo-że więc żyć ja-ko o-so-ba płci żeń-skiej.

- To jak w Czarnoksiężniku z krainy $O z$, powiedziała.

- Jak to?

- Kiedy dom spada na Złą Czarownicę ze Wschodu i koroner odczytuje oświadczenie - koroner z krainy Manczkinów, którego werdykt zaśpiewała teraz z pamięci piskliwie nosowym głosem:

„że ona nie żyje, nie żyje zupełnie!”"105.

Rubinowe pantofelki Dorotki mają magiczną moc, o której mówi Dobra Wróżka: „Zawsze miałaś moc, by wrócić do Kansas”, „Magiczne trzewiki zaraz zabiora cię do domu”, „A więc zamknij oczy. Uderz trzy razy obcasami”. Wydaje się, że dla Stefánie trzewiki pełnią funkcję niemal przedmiotu magicznego, za sprawą którego (w metaforyczny sposób) może powrócić do swojego domu - uzewnętrznić swoją płeć psychiczną. Natomiast unicestwienie Czarownicy ze Wschodu, choć jest wynikiem przypadku (Czarownica została przygnieciona przez spadający dom, w którym znajdowała się Dorotka), można odnieść do próby unicestwienia Stevena przez Stefánie, choć nie jest to takie proste i jednoznaczne. Stefánie dąży jednak do uspójnienia siebie i do tekstualizacji siebie, aby zrozumieć proces tranzycji, na który się zdecydowała i, aby pomóc córce w zrozumieniu całej sytuacji, posługuje się kolejnym hipotekstem. W pierwszą rocznicę waginoplastii przesyła Susanie e-maila z linkiem do książki, którą jej rekomenduje ${ }^{106}$. Jest to nowa biografia Hansa Christiana Andersena. Stefánie swoją wiadomość opatruje zdjęciem przedstawiającym łabędzia, które uruchamia konotację z baśnią Andersena o brzydkim kaczątku. Tym samym bohaterka dokonuje mityzacji swojego losu, bowiem brzydkie kaczątko było niewinne, a skazanie go na wykluczenie przez kaczki, kury, indyka, kobietę, dzieci było okrutne ${ }^{107}$,

103 Tamże, s. 122.

${ }^{104}$ Por. tamże, s. $120,353$.

${ }_{105}$ Tamże, s. 317.

${ }^{106}$ Por. tamże, s. 318.

${ }^{107}$ Por. H.Ch. Andersen, Brzydkie kaczatko, [w:] tegoż, Baśnie t. 1, tłum. S. Beylin, J. Iwaszkiewicz, Warszawa 1975, s. 155-156, 158. 
natomiast sama Stefánie nie może się pochwalić krystaliczną przeszłościa, nie były jej (wówczas jemu) obce agresywne zachowania wobec żony, córki, co nie znaczy, że nie doświadczyła ostracyzmu.

Pożądanie właściwej płci biologicznej, społeczno-kulturowej może być wyrażone nie tylko za pomocą tekstów literackich, obrazów filmowych (widzianych przez bohaterów), konkretnych wizerunków aktorek, pisarek, miss piękności, ale także przez odwołanie do gatunku filmowego. Ciekawy zabieg w konstrukcji postaci można odnaleźć w Telenoweli w reżyserii Pernille’a Fischera Christensena (Dania, Szwecja 2006), łączącej cechy telenoweli i opery mydlanej. Veronice, rozpoczynająca dopiero proces tranzycji, czekająca na decyzję w zakresie przeprowadzenia waginoplastii, z ogromnym przejęciem ogląda telenowelę. Tylko jej znany jest obraz opery mydlanej ${ }^{108}$, bowiem zawsze, gdy ogląda odcinek telenoweli, oko kamery śledzi jej reakcje, a front telewizora nie jest dostępny oczom widza. Na przykład obserwujemy Veronice (w planie amerykańskim) w trakcie domowego seansu: siedzi przed telewizorem i głaszcze psa, jest wzruszona. Bohaterka nawiązuje bliską więź z sąsiadka z bloku, Charlotta, z którą zaczyna śledzić swój ulubiony serial. Oglądanie opery mydlanej przez Veronice koresponduje z jej wrażliwością i jest dla niej odskocznia od formy zarobkowania (przyjmowania klientów mających różne zachcianki seksualne). Wydaje się, że bohaterka, przysłuchując się rozmowom z serialu, chciałaby doświadczyć czegoś podobnego. Pragnie życzliwości ze strony matki, która jedynie odwiedza ją w biegu, zwykle przychodząc na kilka minut i przekazując Veronice w przedpokoju mieszkania pakunek z jedzeniem. Telenowela, choć nie cieszy się specjalnym uznaniem krytyków, potrafi przyciagnąc szerokie grono odbiorców, którego mimowolną przedstawicielka jest Veronice. Wydaje się, że telenowela, mimo pewnej naiwności, „pokazuje, jak za pomocą słów, rozmowy, a nie konwersacji wszystko się da wyjaśnić [...]. W telenoweli naprawia się świat w trakcie rozmowy"109 i o tym prawdopodobnie skrycie marzy bohaterka. Stara się zaspakajać swój głód uczuć, oglądając telenowelę.

Zatem kluczowe dla rozpatrywania doświadczeń bohatera transseksualnego sa: tekstualizacja podmiotu i jego ciałopisanie, a także faktury tekstowe i filmowe, które za pomocą różnych środków wyrazu obrazują

${ }^{108}$ Można oprócz podobieństw wskazać na różnice między telenowelą a operą mydlaną. Telenowela zmierza do zakończenia i koncentruje się na przedstawieniu głównych bohaterów i ich wielkiej miłości. Natomiast opera mydlana może ciagnać się w nieskończoność i najczesściej opowiada o problemach rodziny. Zatem nie prezentuje zdecydowanego podziału bohaterów na dobrych i złych. Każda z postaci może się zmienić w zależności od potrzeb prezentowanych historii (por. P. Nowicki, Co to jest telenowela, [w:] tegoż, Co to jest telenowela, Warszawa 2006, s. 41, 42).

109 Tamże, s. 60. 
owo ciałopisanie. Istotne jest również podejście badacza, któremu bliska jest humanistyka zaangażowana. Badacz w rozważaniach Ryszarda Nycza porusza spetryfikowane postawy, przesądy, zachowania danej wspólnoty czy zbiorowości ${ }^{110}$.

Transseksualność to zagadnienie wieloaspektowe, angażujące wiele dziedzin, domagające się podejścia humanistycznego, postawy akceptacji, która w wielu tekstach kultury jest ujawniana. Wyraźnie jednak brakuje teoretycznej (literaturoznawczej, filmoznawczej) refleksji, którą pragnę przedstawionym szkicem otworzyć, zwracając szczególną uwagę na rolę hipotekstów.

\section{BIBLIOGRAFIA}

Andersen H.Ch., Brzydkie kaczatko, [w:] H.Ch. Andersen, Baśnie t. 1, tłum. S. Beylin, J. Iwaszkiewicz, Warszawa 1975, s. 154-159.

Anderson J. (reż.), Normalny, USA 2003.

Androgynia - miłość, red. Z.W. Dudek, Warszawa 2011.

Antoszewski B., Wizerunek transseksualisty typu kobieta-mężczyzna i suplement do etiopatogenezy zespotu dezaprobaty ptci. Rozprawa habilitacyjna, Łódź 2009.

Arcimowicz K., Pteć pierwsza, druga i trzecia. Alternatywne modele gender w kulturach pozaeuropejskich, [w:] Ucieleśnienia II. Pteć między ciałem i tekstem, red. J. Bator, A. Wieczorkiewicz, Warszawa 2008, s. 69-88.

Bartmiński J., Polifoniczność tekstu czy podmiotu? Podmiot $w$ dialogu $z$ samym soba, [w:] Podmiot w języku i kulturze, red. J. Bartmiński, A. Pajdzińska, Lublin 2008, s. $161-183$.

Baum L.F. (reż.), W Krainie Czarnoksiężnika Oza, Warszawa 1982.

Bauman Z., Ponowoczesne przygody ciała, [w:] Z. Bauman, Ciało i przemoc w obliczu ponowoczesności, Torun 1995, s. 67-109.

Bauman Z., What chance of ethics in the globalized World of consumers?, [w:] Z. Bauman, Does Ethics Have a Chance in a World of Consumers?, London 2009, s. 31-77.

Beauvoir S. de, Druga płeć, tłum. G. Mycielska, M. Leśniewska, Warszawa 2007.

Bielas J., Doświadczenie cielesności. Podmiotowe uwarunkowania transseksualizmu, Kraków 2012.

Bielawska K. (reż.), Mów mi Marianna, Polska 2015.

Bieńkowska M., Transseksualność w badaniach spotecznych - aspekt teoretyczny i metodologiczny, [w:] Psychospołeczne, prawne i medyczne aspekty transpłciowości, red. A.M. Kłonkowska, K. Bojarska, Gdańsk 2014, s. 83-103.

Bieńkowska-Ptasznik, Dylematy badacza-wybrane niuanse z badań nad transseksualizmem, [w:] Kalejdoskop genderowy. W drodze do poznania ptci spoteczno-kulturowej w Polsce, red. K. Slany, B. Kowalska, M. Ślusarczyk, Kraków 2011, s. 459-474.

${ }^{110}$ Por. R. Nycz, Nowa humanistyka w Polsce: kilka bardzo subiektywnych obserwacji, koniektur, refutacji, [w:] Nowa humanistyka. Zajmowanie pozycji, negocjowanie autonomii, red. P. Czapliński, R. Nycz, D. Antonik, J. Bednarek, A. Dauksza i J. Misun, Warszawa 2017, s. 45. 
Bieńkowska-Ptasznik M., Meandry płci-transseksualizm, [w:] Queer studies. Podręcznik kursu, red. J. Kochanowski, M. Abramowicz, R. Biedroń, Warszawa 2010, s. 159-171. Bieńkowska-Ptasznik M., Poza binarnym podziałem płci-rzecz o transseksualizmie, [w:] Teatr płci. Eseje z socjologii gender, red. M. Bieńkowska-Ptasznik, J. Kochanowski, Łódź 2008, s. 187-202.

Bieńkowska-Ptasznik M., Transseksualne doświadczenia ciała, [w:] Corpus delicti rozkoszne ciało. Szkice nie tylko z socjologii ciała, red. E. Banaszak, P. Czajkowski, Warszawa 2010, s. 171-186.

Bieńkowska-Ptasznik M., Uwięzieni w obcym ciele - ciało i tożsamość w doświadczeniu osób transseksualnych, [w:] Ucieleśnienia II. Pteć między ciałem i tekstem, red. J. Bator i A. Wieczorkiewicz, Warszawa 2008, s. 247-262.

Breska-Kruszewska J., Rachoń D., Medyczne aspekty transpłciowości-rozpoznanie i postepowanie lecznicze, [w:] Psychospołeczne, prawne i medyczne aspekty transptciowości, red. A.M. Kłonkowska, K. Bojarska, Gdańsk 2014, s. 165-177.

Buczkowski A., Reprodukowanie ciała uptciowionego, [w:] Społeczne tworzenie ciała. Pteć kulturowa i płeć biologiczna, Kraków 2005, s. 209-238.

Butler J., Uwiktani w płeć, tłum. K. Krasuska, Warszawa 2008.

Choińska B., Podmiot i dyskurs w świetle myśli wybranych przedstawicieli postrukturalizmu francuskiego, Kraków 2014.

Christensen P.F. (reż.), Telenowela, Dania, Szwecja 2006.

Czarnocka M., Podmiot poznania a nauka, Torun 2012.

Czcibor-Piotrowski A., Cud w Esfahanie, Warszawa 2011.

Czcibor-Piotrowski A., Nigdy dość mirakle, Warszawa 2011.

Czcibor-Piotrowski A., Rzeczy nienasycone, Warszawa 2010.

Cukor G. (reż.), Kolacja o ósmej, USA 1933.

Darska B., Wstep. Patrzeć z nieufnościa, [w:] Kultura wobec odmienności. Dyskursy. Film / Telewizja t. 1, red. B. Darska, Warszawa 2009, s. 6-8.

Dąbrowa E., Kim jest dziś inny w Polsce?, [w:] Spogladajac na stereotyp, red. R. Kusek, J. Sanetra-Szeliga, Kraków 2014, s. 12-31.

Dębińska M., Queer i polityka cierpienia. Strategie narracyjne i polityczne osób trans $w$ Polsce, [w:] Strategie queer. Od teorii do praktyki, red. M. Kłosowska, M. Drozdowski, A. Stasińska, Warszawa 2012, s. 226-244.

Dynarski W., Kłonkowska A., Stownik pojęć, [w:] Sytuacja osób LGBT. Raport za lata 2010 i 2011, red. M. Makuchowska, M. Pawlęga, Warszawa 2012, s. 220-227.

Dynarski W., Pacewicz P., Wszyscy jesteśmy trans, [w:] Zakazane miłości, red. M. Konarzewska, P. Pacewicz, Warszawa 2008, s. 187-201.

Erenc J., Teoria grupy społecznej a mechanizmy wykluczenia, [w:] Społecznie wykluczeni. Niewygodni, nienormatywni, nieprzystosowani, nieadekwatni, red. A.M. Kłonkowska, M. Szulc, Gdańsk 2013, s. 11-26.

Fajkowska-Stanik M., Transseksualizm i rodzina. Przekaz pokoleniowy wzorców relacyjnych $w$ rodzinach transseksualnych kobiet, Warszawa 2001.

Faludi S., W ciemni, tłum. J. Bednarek, Warszawa 2017.

Fleming V. (reż.), Czarnoksiężnik z Krainy Oz, USA 1939.

Gajda J., Trzecia płeć, [w:] Antropologia kulturowa. Kultura obyczajowa poczatku XXI wieku, Kraków 2015, s. 80-82. 
Goffman E., Piętno. Rozważania o zranionej tożsamości, tłum. A. Dzierżyński, J. Tokarska-Bakir, Gdańsk 2005.

Grodzka A., mam na imię Ania, Warszawa 2013.

Grünberg S., Reszke K. (reż.), TransAkcja, Polska 2010.

Halberstam J., Transgender Butch: Butch/FTM Border Wars and the Masculine Continuum, [w:] Female Masculinity, Durham, London 2018, s. 141-175.

Hemingway E., Rajski ogród, tłum. M. Michałowska, Warszawa 1989.

Holland A. (reż.), Historia Gwen Arauja, USA 2006.

Hooper T. (reż.), Dziewczyna z portretu, Belgia, Dania, Niemcy, USA, Wielka Brytania 2015. Irving J., W jednej osobie, tłum. M. Moltzan-Małkowska, Warszawa 2012.

Jakubowski T., Inność poprzez wieki - historia transptciowości, [w:] Inność/Różnorodność w języku i kulturze, red. E. Bogdanowska-Jakubowska, Katowice 2015, s. 109-122.

Kalatzidis K. (reż.), Dziewczyny z wyboru, Grecja 2001.

Kalejdoskop genderowy. W drodze do poznania ptci społeczno-kulturowej $w$ Polsce, red. K. Slany, B. Kowalska, M. Ślusarczyk, Kraków 2011.

Kaniewska B., „I tak taki jest się, jaki jest”- wokót kategorii podmiotu literackiego, [w:] Podmiot w języku i kulturze, red. J. Bartmiński, A. Pajdzińska, Lublin 2008, s. 87-108.

Kapuściński R., Spotkania z Innym jako wyzwanie XXI wieku. Wykład wygłoszony 1 października 2004 z okazji przyznania tytutu doktora honoris causa Uniwersytetu Jagiellońskiego, Kraków 2004.

Kasperski E., Między poetyka i antropologia postaci. Szkic zagadnień, [w:] Postać literacka. Teoria i historia, red. nauk. E. Kasperski, współred. B. Pawłowska-Jądrzyk, Warszawa 1998, s. 9-41.

Kasperski E., Świat człowieczy. Wstęp do antropologii literatury, Pułtusk-Warszawa 2006.

Kimmel M., Genderowie ciało, [w:] Społeczeństwo genderowe, red. A.M. Kłonkowska, tłum. A. Czerniak, A.M. Kłonkowska, Gdańsk 2015, s. 446-503.

Kłonkowska A.M., Płeć: dana czy zadana? Strategie negocjacji (nie)tożsamości transpłciowej w Polsce, Gdańsk 2017.

Kondracka M., Spotkanie z Innym - refleksje teoretyczno-empiryczne, [w:] Społeczeństwo wobec Innego. Kategoria Innego w naukach społecznych $i \dot{z} y c i u$ publicznym, red. L. Dziewięcka-Bokun, A. Śledzińska-Simon, Toruń 2010, s. 61-73.

Kosińska K., Brudny róż. Zapiski z życia, którego nie było, Warszawa 2015.

Krasuska K., Transgender, [w:] Encyklopedia gender. Pteć w kulturze, red. M. Rudaś-Grodzka, K. Nadana-Sokołowska, A. Mrozik, K. Szczuka, K. Czeczot, B. Smoleń, A. Nasiłowska, E. Serafin, A. Wróbel, Warszawa 2014, s. 545-547.

Kryszk K.(R.), Buddyzm a transptciowość, [w:] Transpłciowość - androgynia, red. A. Kłonkowska, Gdańsk 2012, s. 59-84.

Kujawska-Kot A., Intertekstualny wymiar kobiecości w odniesieniu do osób transptciowych, [w:] Tożsamość. Kultura. Nowoczesność t. 1, red. B. Morzyńska-Wrzosek, M. Kurkiewicz, I. Szczukowski, Bydgoszcz 2017, s. 296-312.

Kujawska-Kot A., Literackie odpowiedzi na konstelacje obcości i inności, [w:] Kultury obcości, red. M. Jedliński, K. Witczak, Bydgoszcz 2016, s. 64-77.

Kusiak A., Pamiętniki Pani de Sancy przebranej za opata. Transgenderyzm na dworze Ludwika XIV, [w:] Odmiany odmieńca. Mniejszościowe orientacje seksualne z perspektywy gender, red. T. Basiuk, D. Ferens, T. Sikora, Katowice 2002, s. 25-43. 
Lizurej M., Mit androgyne - wzór tamania barier ptci. Teoria queer wobec powieści Olgi Tokarczuk „Dom dzienny, dom nocny”, [w:] Zrozumieć pleć. Studia interdyscyplinarne II, red. A. Kuczyńska, E.K. Dzikowska, Wrocław 2004, s. 509-522.

Maj J., Przełamujac dychotomię płci w Polsce. Porównanie sytuacji osób transgenderowych w Polsce oraz innych krajach europejskich, [w:] Postpłciowość? Praktyki i narracje tożsamościowe w ponowoczesnym świecie, red. A.E. Banot, A. Barabasz, R. Majka, Bielsko-Biała 2012, s. 166-185.

Majka-Rostek D., Komunikacja genderowa jako komunikacja międzykulturowa, [w:] Zrozumieć płeć. Studia interdyscyplinarne II, red. A. Kuczyńska, E.K. Dzikowska, Wrocław 2004, s. 258-266.

Mandal E., Pojmowanie fenomenu ptciowości w psychologii, [w:] Zrozumieć pteć. Studia interdyscyplinarne II, red. A. Kuczyńska, E.K. Dzikowska, Wrocław 2004, s. $196-211$.

Migalska A., Transseksualna opowieść o władzy, czyli czego nie wiemy o kobiecości, [w:] Kalejdoskop genderowy. W drodze do poznania płci społeczno-kulturowej $w$ Polsce, red. K. Slany, B. Kowalska, M. Ślusarczyk, Kraków 2011, s. 475-503.

Miczka T., Cielesny aspekt podmiotowości w kinie, [w:] Kino: Gest-Ciało-Ruch. Film w perspektywie systemów komunikowania niewerbalnego, red. A. Gwóźdź, Wrocław 1990, s. 125-135.

Mizielińska J., (De)Konstrukcje kobiecości, Gdańsk 2004.

Mrówka K., Androgyn, Szczecin 2005.

Nilsson J., Kochajacy na marginesie, tłum. P. Pollak, Zakrzewo 2009.

Nowicki P., Co to jest telenowela, Warszawa 2006.

Nycz R., Intertekstualność i jej zakresy: teksty, gatunki, światy, [w:] Między tekstami: Intertekstualność jako problem poetyki historycznej: studia, red. J. Ziomek, J. Sławiński, W. Bolecki, Warszawa 1992, s. 9-42.

Nycz R., Nowa humanistyka w Polsce: kilka bardzo subiektywnych obserwacji, koniektur, refutacji, [w:] Nowa humanistyka. Zajmowanie pozycji, negocjowanie autonomii, red. P. Czapliński, R. Nycz oraz D. Antonik, J. Bednarek, A. Dauksza i J. Misun, Warszawa 2017, s. 23-48.

Peirce K. (reż.), Nie czas na tzy, USA 1999.

Pelczar M.A., Co i kto nie „przechodzi”. (Nie)widoczność, „passing” a nie/normatywność trans, [w:] Strategie queer. Od teorii do praktyki, red. M. Kłosowska, M. Drozdowski, A. Stasińska, Warszawa 2012, s. 205-225.

Potter S. (reż.), Orlando, Francja, Holandia, Rosja, Wielka Brytania, Włochy 1992.

Prosser J., Second Skins. The Body Narratives of Transsexuality, New York 1998.

Puenzo L. (reż.), XXY, Argentyna, Francja, Hiszpania 2007.

Richardson N., Transsexed bodies, [w:] Transgressive Bodies. Representations in Films and Popular Culture, London, New York 2016, s. 121-162.

Rogowska-Stangret M., Ciało - poza Innościq i Tożsamościq. Trzy figury ciała $w$ filozofii wspótczesnej, Gdańsk 2016.

Rosner K., Dialog jako temat filozofii wspótczesnej: Buber, Gadamer, Habermas, [w:] Dialog. Idea i doświadczenie, red. S. Kruszyńska, K. Bembennek, I. Krupiecka, Gdańsk 2011, s. 15-32. 
Rzeczkowski M., Trans-optymista, wybór tekstów, [w:] Psychospoteczne, prawne i medyczne aspekty transpłciowości, red. A.M. Kłonkowska, K. Bojarska, Gdańsk 2014, s. $13-62$.

Sarmińska-Górecka M., Ciało jako kostium, [w:] Colloquia Communia. Kobiecość?, red. E. Hyży, Toruń 2008, s. 163-184.

Sieradzan J., Ile ptci ma człowiek, „ALBO albo. Problemy psychologii i kultury” 2009 nr 2-3.

Sonderegger Ch. (reż.), Coby, Francja, USA 2017.

Sternberg J. von (reż.), Marocco, USA 1930.

Szczęsna E., Technologie cyfrowe i humanistyka - wzajemne relacje, [w:] Nowa humanistyka. Zajmowanie pozycji, negocjowanie autonomii, red. P. Czapliński, R. Nycz, D. Antonik, J. Bednarek, A. Dauksza i J. Misun, Warszawa 2017, s. 399-417.

Švankmajer J. (reż.), Možnosti dialogu, Czechosłowacja 1982.

Tarnowska M., Kiedy odmawiamy „obcym” części człowieczeństwa? Uwarunkowania zjawiska infrahumanizacji, [w:] Wobec obcych. Zagrożenia psychologiczne a stosunki międzygrupowe, red. M. Kofta, M. Bilewicz, Warszawa 2011, s. 168-188.

Terentowicz-Fotyga U., „Drugi koniec świata”: Orlando i Fale, [w:] U. Terentowicz-Fotyga, Semiotyka przestrzeni kobiecych w powieściach Virginii Woolf, Lublin 2006, s. $73-108$.

Tokarczuk O., Dom dzienny, dom nocny, Kraków 2011.

Trzódek J., Na tropach podmiotu. Między filozoficznym a empirycznym ujęciem podmiotowości, Kraków 2013.

Uekrongtham E. (reż.), Piękny bokser, Tajlandia 2004.

Uspienski B., Strukturalna wspólnota różnych sztuk. Ogólne zasady organizacji dzieła malarskiego i literackiego, [w:] B. Uspienski, Poetyka kompozycji: struktura tekstu artystycznego i typologia form kompozycji, tłum. P. Fast, Katowice 1997, s. 191-244.

Vallée J.-M. (reż.), Witaj w klubie, USA 2013.

Wat A., Hermafrodyta, [w:] A. Wat, Bezrobotny Lucyfer $i$ inne opowieści, Warszawa 1993, s. 154-166.

Wieczorkiewicz A., Dziwna kobiecość Barbary Urselin, [w:] Ucieleśnienia II. Pteć między ciałem i tekstem, red. J. Bator i A. Wieczorkiewicz, Warszawa 2008, s. 53-68.

Woolf V., Orlando, tłum. T. Bieroń, Poznań 1994.

Zamojski D., Aleksandra Zamojska jest mężczyzna, Warszawa 2005.

Zieniewicz A., Aneks. Podmiot w literaturze po 1989 roku. Cudownie zmartwychwstaty, [w:] Podmiot w literaturze polskiej po 1989 roku. Antropologiczne aspekty konstrukcji, red. Ż. Nalewajk, Warszawa 2011, s. 270-294.

Ziemińska R., Niezgodność ptci odczuwanej z ptcia metrykalnq. Osoby transptciowe, [w:] Niebinarne i wielowarstwowe pojęcie ptci. Próba inkluzji danych o osobach interptciowych i niebinarnych, Warszawa 2018, s. 75-107.

Ziemińska R., Niebinarne i wielowarstwowe pojęcie ptci. Próba inkluzji danych o osobach interptciowych i niebinarnych, Warszawa 2018, s. 121-147.

Zientak S., Miraże, Warszawa 2015. 


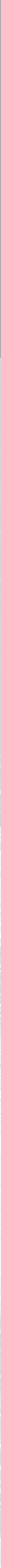


